\title{
Contributions to and review of dicrocoeliosis, with special reference to the intermediate hosts of Dicrocoelium dendriticum
}

\author{
M. Y. MANGA-GONZÁLEZ*, C. GONZÁLEZ-LANZA, E. CABANAS and R. CAMPO \\ Consejo Superior de Investigaciones Cientificas (CSIC), Estación Agrícola Experimental, Apdo. 788, 24080 León, Spain
}

SUMMARY

An epidemiological study on dicrocoeliosis caused by Dicrocoelium dendriticum was carried out on sheep, molluscs and ants in the mountains of León province (NW Spain) between 1987-1991. The results concerning the intermediate hosts and a review of some aspects of dicrocoeliosis are summarized. Mollusc collection for the helminthological study was random throughout the study area at fortnightly intervals. Twenty-nine Gastropoda species were identified. D. dendriticum infection was only detected in $2.98 \%$ of the 2084 Helicella itala examined and in $1.06 \%$ of $852 \mathrm{H}$. corderoi. The highest infection prevalence was detected in H. itala in September and in H. corderoi in February. Daughter sporocysts with welldeveloped cercariae predominated in spring and autumn. Infection prevalence increased with mollusc age and size. Ants were collected from anthills or plants to which they were attached. The behaviour of ants in tetania was followed. Twentyone Formicidae species were identified, but only the following harboured D. dendriticum: Formica cunicularia (1158 examined specimens, $0.69 \%$ infection prevalence, 2-56 metacercariae per ant); $F$. sanguinea $(234,1 \cdot 28 \%, 2-63) ; F$. nigricans $(1770,4.97 \%, 1-186) ; F$. rufibarbis $(288,6.59 \%, 2-107)$. In a flat area close to León town, $95.39 \%$ of the 2085 F. rufibarbis specimens collected in tetania contained metacercariae (1-240) in the abdomen. These were used for parasite characterization by isoelectric focusing and to infect lambs and hamsters. Only one brainworm per ant was found.

Key words: Dicrocoelium dendriticum, mollusc and ant intermediate hosts.

\section{INTRODUCTION}

Dicrocoelioses are parasite infections caused by the species of the genus Dicrocoelium Dujardin, 1845 (Trematoda, Digenea), although mainly by Dicrocoelium dendriticum (Rudolphi, 1819) Looss, 1899. This parasite, which cycles in land molluscs and ants, is located in the bile ducts and gall bladders of numerous species of domestic and wild mammals, mainly ruminants, which act as definitive hosts in several countries in Europe, Asia, America and North Africa (Malek, 1980). D. dendriticum is a very common species in ruminants in the Iberian peninsula (Cordero, Castañón \& Reguera, 1994). Moreover, this parasite can also occasionally infect humans (Mohamed \& Mummery, 1990). Infection of the definitive hosts occurs by ingesting the ants which harbour infective metacercariae.

The genus Dicrocoelium is included in the subfamily Dicrocoeliinae Looss, 1899, of the Dicrocoeliidae Family Odhner, 1911. According to La Rue (1957), this family belongs to the superfamily Plagiorchioidea, suborder Plagiorchiata, order Plagiorchiida and superorder Epitheliocystida. The most important species of this genus which infect ruminants are: Dicrocoelium dendriticum; D. hospes Looss, 1907, D. chinensis Tang \& Tang, 1978 and D. suppereri Hinaiday, 1983 (syn. D. orientalis

* Corresponding author: Tel: +34987 317156. Fax: +34987317161. E-mail: y.manga@eae.csic.es
Sudarikov et Ryjikov, 1951). D. dendriticum is found in America, Asia, North Africa and Europe (Malek, 1980) including practically all of the Iberian Peninsula (Cordero et al. 1994). The second, the third and the fourth species have been found in Africa (Lucius, 1981), Asia (Tang et al. 1983) and the old Soviet Union and Austria (Hinaidy, 1983), respectively.

This paper mainly concerns dicrocoeliosis produced by $D$. dendriticum as it is the most widespread amongst the ruminants of several countries. For a long time this parasite was confused with an immature form of Fasciola hepatica, as both trematodes are frequently found together in the liver of ruminants. Its description thus came late. The synonymy of this parasite is complex, due to the different generic and specific denominations received (Mapes, 1951; Schuster, 1987).

Dicrocoeliosis causes irritation of the mucosa of the large bile ducts in definitive hosts. This explains the proliferation and increase in the secretion of the glandular cells as well as cholangitis and cholangiectasis of the septal and hepatic bile ducts, granulomatous type portal hepatitis associated with portal, septal and perisinusoidal fibrosis and vacuolar degeneration of the hepatocytes (Dhar \& Singh, 1963 ; Wolff, Hauser \& Wild, 1984; SanchezCampos et al. 1996; Ferreras et al. 1997). This disease is generally chronic and the immune response does not protect from reinfection. Experimental studies carried out in lambs infected with 1000 and 
3000 D. dendriticum metacercariae showed that the first egg elimination took place between days 49 and 79 post-infection (Campo, Manga-González \& González-Lanza, 2000), while the first detection of IgG antibodies by ELISA technique was observed on day 30 p.i. Maximum antibody levels were obtained 60 days p.i. and remained high until the experiment ended 180 day p.i. (González-Lanza et al. 2000). Moreover the studies of the liver and hepatic lymph nodes (from the lambs slaughtered 2 months p.i.) immunolabelled by avidin-biotin complex system showed that the parasite induced a humoral and cell-mediated local immune response that contributed to the inflammation observed but did not seem effective for the destruction of the parasite (Ferreras et al. 2000).

The economic and health significance of dicrocoeliosis is partly due to the direct losses occasioned by the confiscation of altered livers (Del Rio, 1967; Lukin, 1980; Karanfilovski, 1983) and also the indirect ones caused by the digestive disorders derived from the hepatobiliary alterations caused by these parasites, such as decreased animal weight (Boray, 1985), growth delay (Hohorst \& Lämmler, 1962), reduced milk production (Cavani et al. 1982), amongst others. Moreover, the additional costs incurred by the application of anthelminthic treatments, to which the animals must be subjected, have to be considered.

The life cycle of Dicrocoelium dendriticum is extremely complex because land molluscs and ants are required as first and second intermediate hosts, respectively. Until Krull \& Mapes (1952, 1953) managed to complete the life cycle for the first time, numerous studies were carried out over more than a century to try elucidate it (reviewed by Mapes, 1951 and Del Río, 1967). The adults of the genus $D$. dendriticum live in the liver and bile ducts of the definitive hosts where they lay their embryonated eggs which pass through the intestine to be eliminated in the faeces. Egg hatching and miracidium liberation only occur in the intestine of numerous species of land molluscs that act as first intermediate hosts. The miracidium penetrates the intestinal wall of the mollusc and settles in the hepatopancreas, where it becomes a mother sporocyst, which takes the shape of the spaces between hepatopancreatic lobules because it has no wall itself. This larval stage produces sacciform daughter sporocysts with their own wall in which cercariae are formed when they are well developed. These abandon the sporocysts when they are mature and migrate to the respiratory chamber of the mollusc where they are covered in slime. The slimeballs are eliminated through the pneumostoma by the respiratory movements of the snail. When these slimeballs are ingested by different species of ants, which act as second intermediate hosts, the cercariae cross the craw of the ants, lose their tail and one of them (sometimes 2 or 3 ), called the “brainworm”, settles in the suboesophageal ganglion of the ant and the rest become metacercariae in the abdomen. When the temperature falls, the brainworm alters the behaviour of the ant by causing tetania of its mandibular muscles. Due to this the ant remains temporarily attached to grass and this promotes ingestion by the definitive host. The mature abdominal metacercariae excyst in the intestine, the young flukes migrate to the liver through the opening of the common bile duct (sometimes the portal circulation) and become adult worms in the bile duct. When these are mature, they lay eggs which exit in the faeces of the host and this allows the life cycle to begin again. A more detailed description of the adult worm and of the different stages of the parasite can be found in Manga-González (1999) and in Manga-González \& Quiroz-Romero (1999).

The role played by molluscs in the epidemiology of dicrocoeliosis is very important as $D$. dendriticum egg hatching and miracidium liberation only occur in the intestine of the molluscs that act as intermediate hosts. Moreover, the parasite multiplies enormously by asexual reproduction inside them (numerous cercariae can be formed from one ingested egg). This increases the possibilities of parasite transmission. Since Piana (1882) first encountered the long-tailed cercaria in Helix carthusiana (= Monacha $(M$.) cartusiana), which was later described by Von Linstow (1887) as Cercaria vitrina (from Zebrina detrita) and associated with Dicrocoelium dendriticum, many studies have been carried out to discover the mollusc species which act as first intermediate hosts for this parasite. More than 100 mollusc species (Gastropoda, Pulmonata, Stylommatophora) have been found receptive to $D$. dendriticum under natural and laboratory conditions (some of them are mentioned in the Discussion below). It can be deduced from this that $D$. dendriticum shows markedly little specificity as regards its first intermediate host. In addition the parasite can develop in various mollusc species in the same area: Manga-González (1987, 1992) found 11 species of Helicidae infected with the parasite in the province of León (Spain). The life history of the mollusc intermediate hosts is of great epidemiological interest, as regards both the ingestion periods of $D$. dendriticum eggs, dependent on the molluscs' activity, and the survival of the parasite in them. Species, age and nutritional state of the molluscs, infective dose, ambient temperature and relative humidity, amongst other aspects, all influence the development of larval stages of this digenean in the first intermediate hosts. Gómez et al. (1996) observed a higher infection percentage and faster development of $D$. dendriticum in Cernuella (Xeromagna) cespitum arigonis than in Cernuella (Cernuella) virgata, although both species had been tested at the same time with identical doses of eggs 
and kept in the same conditions $\left(20^{\circ} \mathrm{C}\right.$ and $40 \%$ relative humidity).

The importance of ants in the epidemiology of dicrocoeliosis is mainly due to their abundance, wide distribution and the fact that the alteration in their behaviour, caused by the presence of the parasite in the brain, make their ingestion by definitive hosts easy when the infected ones are in tetania on plants. Since Krull \& Mapes (1952) showed that an ant (Formica fusca) acted as second intermediate host of D. dendriticum, various authors have endeavoured to discover the species of ants which act as secondary intermediate hosts for $D$. dendriticum in nature and under experimental conditions, the prevalence and intensity of the infection, the behaviour of infected ants and the risk period for infection of the definitive hosts, amongst other aspects. At least 21 Formicidae species mainly from Formica genus have been described as receptive to this parasite in different countries. Some of these species are mentioned in the Discussion section.

Tegelström, Nilsson \& Wyoni (1983) used isoelectric focusing to study the proteins of the ant species Formica rufa, $F$. polyctena and $F$. pratensis, in head and thorax homogenate. These authors detected the presence of about 68 bands of general proteins and 18 of non-specific esterases among the three ant species. However, according to our information, no studies using isoelectric focusing on thin-layer polyacrylamide gel techniques have been carried out to characterize the larval stages of $D$. dendriticum and their detection in ants, although they have been done for the larval stages found in the molluscs (Campo et al. 1992, and other unpublished information) and for the adult parasite (Campo et al. 1998).

The application of efficacious dicrocoeliosis control measures, which have not been satisfactory so far (Eckert \& Hertzberg, 1994), requires good diagnosis and knowledge of the epidemiology of the disease. Nevertheless, integrated studies of the $D$. dendriticum transmission process are scarce - possibly due to the long length of its life cycle and its great complexity. So, as a basis for the design of strategic effective control programmes, we decided to throw light on the epidemiological model in an area in the mountains of León province (Spain) where we had previously detected the maximum infection prevalence in randomly sampled sheep $(73.7 \%)$ and the highest values of the maximum (5340) and mean $(398 \cdot 8 \pm 5)$ numbers of eggs per gram (Manga-González, González-Lanza \& DelPozo, 1991). It is necessary to take into account that the epidemiology of this parasitosis is influenced by local conditions such as: existence of definitive hosts (domestic or wild) receptive to the parasite, farming model, animal handling, presence, biology and ethology of the molluscs and ants which act as first and second intermediate hosts, meteorological factors, soil type and vegetation. Simultaneous studies on definitive and intermediate $D$. dendriticum hosts were carried out in order to discover the shedding kinetic of eggs per marked sheep, the mollusc and ant species acting as intermediate hosts and various aspects of their life history, the dynamics of their infection and degree of development of the larval stages they harbour, the transmission period to the definitive hosts via detection in the field of ants with infective metacercariae, and the influence of the biotic and abiotic factors on the dynamic of the mollusc and ant populations on the degree of development of the larval stages and on the infection rate of the definitive and intermediate hosts. This paper reports on the data relative to the molluscs, ants and their infection by $D$. dendriticum.

In addition, results relating to the prevalence and intensity of $D$. dendriticum metacercariae in Formica rufibarbis Fabricius, 1794 (Formicidae) collected in tetania from around the town of León (Spain) are included. This was in order to obtain metacercariae to carry out the morphological and isoenzymatic study and experimentally infect lambs and hamsters in order to study different aspects of experimental dicrocoeliosis.

\section{MATERIALS AND METHODS}

\section{Molluscs}

The study was carried out over two consecutive years from June, 1987 to May, 1989 in the valley of Redipollos (U.T.M. co-ordinates: 30TUN1663; altitude 1100 to $1400 \mathrm{~m}$ ), situated in the upper basin of the Porma in the province of León (NW Spain), in an area measuring 560 hectares used as pasture by a communal flock of 120 sheep. The climate is continental within the Mediterranean-Atlantic transition. Before beginning sampling, a survey was done in the area which allowed us to distinguish the following habitats and their extension $(\%)$ : pasture on limestone $(46 \%)$ ), limestone wall $(19 \%)$, pasture on acid soil (1\%), pasture-Genista hispanica complex $(22 \%)$ and Arctostaphylus uva-ursi areas (13\%) where the botanical composition was studied. Three zones were established in the valley according to the movement of the sheep flock throughout the year: Zone A, known as "Peña El Castillo", situated to the west of Redipollos, with slopes facing the 4 compass points and used by the flock between December and April; Zone B, a slope to the south close to the village, facing north-west and used as pasture throughout the year; Zone $\mathrm{C}$, a slope to the east quite far away from the village, facing north and used by the flock between April and December. The area covered by the different habitats in the whole study area and in the three separate zones was estimated using a planimeter.

Collections to discover the existing mollusc 
species, their distribution and various aspects of their biology and ecology were carried out on three plot types, in different zones, habitats and orientations of the Redipollos valley. The number and the size of the plots were: ten $4 \times 4 \mathrm{~m}$, forty-two $1 \times 1 \mathrm{~m}$, one hundred and one $0.5 \times 0.5 \mathrm{~m}$. Biotic and abiotic variables were checked in each plot at monthly intervals. These results have not yet been published.

Snail collection for the helminthological study was carried out at random over the area at fortnightly intervals. A distance of $10 \mathrm{~m}$ from the plots established for the mollusc population dynamic study was respected. The monthly values of environmental temperature and precipitation came from the two nearest stations and were supplied by the staff of the Duero basin Meteorological Service (Valladolid, Spain). The average environmental temperatures and precipitation in the different months were: $1.5{ }^{\circ} \mathrm{C}$, $190.9 \mathrm{~mm}$ in January; $1.7^{\circ} \mathrm{C}, 111.8 \mathrm{~mm}$ in February; $3 \cdot 4{ }^{\circ} \mathrm{C}, 81 \mathrm{~mm}$ in March; $3 \cdot 3{ }^{\circ} \mathrm{C}, 203 \cdot 4 \mathrm{~mm}$ in April; $9 \cdot 2{ }^{\circ} \mathrm{C}, 120.7 \mathrm{~mm}$ in May; $11{ }^{\circ} \mathrm{C}, 89.8 \mathrm{~mm}$ in June; $14.3{ }^{\circ} \mathrm{C}, 94.2 \mathrm{~mm}$ in July; $13.9^{\circ} \mathrm{C}, 38.4 \mathrm{~mm}$ in August; $11^{\circ} \mathrm{C}, \quad 67.6 \mathrm{~mm}$ in September; $8.1^{\circ} \mathrm{C}$, $262.5 \mathrm{~mm}$ in October; $4.7^{\circ} \mathrm{C}, 117 \mathrm{~mm}$ in November; and $1.9^{\circ} \mathrm{C}, 108 \mathrm{~mm}$ in December. The live molluscs were taken to the laboratory and the different species were identified, the specimens were measured and their degree of maturity noted. Material fixation and later examination of the molluscs were done as specified by Manga-González (1983). The determination of the mollusc species was carried out primarily based on conchological and anatomical traits, mainly of the different genital apparatus structures. The publications of Riedel (1972), Kerney, Cameron \& Jungbluth (1983), MangaGonzález (1983), Castillejo (1998), Wiktor (2000), amongst others, were consulted. The helminthological study was done according to Manga-González (1987). The molluscs were anaesthetised and dissected in order to detect $D$. dendriticum daughter sporocysts in the hepatopancreas using a stereomicroscope and to study their degree of development using an optical microscope. Infection intensity was semi-quantitatively estimated on the basis of the lesser or greater extent to which the hepatopancreas was invaded by sporocysts. The length and width of all the sporocysts up to 100 extracted complete from each mollusc were measured under the microscope and, if the number was higher, $10 \%$ of the rest were also measured. The developmental stage of these sporocysts was studied for each of the infected molluscs in vivo. Determination of parasite species was carried out by means of morphoanatomical, chaetotaxic and isoelectric focusing studies and also by comparing the larval stages with those obtained by experimental infection. In order to discover the possible influence of the collection month of the molluscs studied, their age (established according to the development degree of the genitalia and several shell characteristics), zone and habitat from which they came, on the infection prevalence by $D$. dendriticum, the data were analysed using the $\chi^{2}$ test and the $2 \times 2$ contingency tables.

\section{Ants}

Three types of sampling were carried out to collect ants in the mountain area of Redipollos, which has already been described for the mollusc study. The first consisted of introducing a $2.5 \mathrm{~cm}$ diameter by $9 \mathrm{~cm}$ long polyurethane tube, in duplicate at ground level, into 40 of the 101 plots measuring $0.5 \times 0.5 \mathrm{~m}$ established to study the mollusc populations. This type of sampling was only carried out on two occasions (October and November, 1988) due to the unsatisfactory results obtained. These tubes, filled with a mixture of formol at 4 parts per thousand and glycerine, acted as traps for the insects which fell into them and were removed after 8 days. The second type of sampling was carried out at the same time as the collection of molluscs for the helminthological study. A large number of ants was collected directly from 53 anthills found in the different habitats, 23 in zone A, 16 in zone B and 14 in zone C. The third type of sampling was carried out by individually collecting ants which were in tetania in the area surrounding the anthills. In addition, for several days various $F$. pratensis anthills were controlled in zone $\mathrm{C}$ to detect ants in tetania and record their behaviour. The number of ants in tetania, the type of plants used to support them, the position of the ants, the geographical orientation, the hours spent in tetania and the times when they started activity, as well as the temperature and relative humidity at ground level at those times were all recorded in this study.

For the studies on experimental dicrocoeliosis in lambs and hamsters and for the enzymatic characterization of $D$. dendriticum metacercariae, between 1992 and 1998 ants of the $F$. rufibarbis species in tetania were collected from 9 sites in the flat area near the town of León (Spain). They were situated in the lower basin of the rivers: Porma (Mellanzos, San Cipriano del Condado and Valdelafuente), Torio (Navatejera) and Bernesga (Grulleros and Villa de Soto), as well as the banks of the river Esla (Villafalé, Palanquinos and Valencia de Don Juan) near where it joins these tributaries. These sites, at altitudes of between 763 and $903 \mathrm{~m}$, were chosen because $D$. dendriticum infection of molluscs and sheep had previously been detected there. Ants were collected from May to October, mainly in the early hours of the morning and sometimes in the afternoons. The collection time, ambient temperature and relative humidity at ground level, general weather conditions and type of plant were also noted down at the time of collection. 
Table 1. Prevalence of infection by $D$. dendriticum of the Gastropoda species studied

\begin{tabular}{|c|c|c|}
\hline Mollusc species & $\begin{array}{l}\text { Number } \\
\text { examined }\end{array}$ & $\begin{array}{l}\text { Percentage } \\
\text { infected }\end{array}$ \\
\hline \multicolumn{3}{|l|}{ Subclass PULMONATA } \\
\hline \multicolumn{3}{|l|}{ Order STYLOMMATOPHORA } \\
\hline \multicolumn{3}{|l|}{ Agriolimacidae } \\
\hline Deroceras (Agriolimax) agreste (Linnaeus) & 9 & 0 \\
\hline Deroceras (Agriolimax) reticulatum (Müller) & 24 & 0 \\
\hline \multicolumn{3}{|l|}{ Arionidae } \\
\hline Arion (Arion) ater (Linnaeus) & 18 & 0 \\
\hline Arion (Arion) lusitanicus (Mabille) & 4 & 0 \\
\hline Arion (Arion) rufus (Linnaeus) & 21 & 0 \\
\hline Arion (Microarion) intermedius (Normand) & 1 & 0 \\
\hline \multicolumn{3}{|l|}{ Buliminidae } \\
\hline Faminia (Faminia) quadridens (Müller) & 35 & 0 \\
\hline \multicolumn{3}{|l|}{ Chondrinidae } \\
\hline Chondrina kobelti cliendentata Gittenberger & 151 & 0 \\
\hline \multicolumn{3}{|l|}{ Cochlicopidae } \\
\hline Cochlicopa lubrica (Müller) & 45 & 0 \\
\hline \multicolumn{3}{|l|}{ Helicidae* } \\
\hline Cepaea (Cepaea) nemoralis (Linnaeus) & 71 & 0 \\
\hline \multicolumn{3}{|l|}{ Hygromiidae } \\
\hline Helicella (Helicella) itala (Linnaeus) & 2084 & $2 \cdot 98$ \\
\hline Helicella corderoi Gittenberger \& Manga & 852 & $1 \cdot 06$ \\
\hline Oestophora sp. & 1 & 0 \\
\hline Oestophorella buvinieri (Michaud) & 12 & 0 \\
\hline \multicolumn{3}{|l|}{ Pupillidae } \\
\hline Lauria (Lauria) cylindracea (Da Costa) & 7 & 0 \\
\hline Pupilla (Pupilla) muscorum (Linnaeus) & 3 & 0 \\
\hline \multicolumn{3}{|l|}{ Pyramidulidae } \\
\hline Pyramidula rupestris (Draparnaud) & 25 & 0 \\
\hline \multicolumn{3}{|l|}{ Valloniidae } \\
\hline Vallonia costata (Müller) & 3 & 0 \\
\hline Vallonia excentrica Sterki & 3 & 0 \\
\hline \multicolumn{3}{|l|}{ Vertiginidae } \\
\hline Truncatellina cylindracea (Férussac) & 2 & 0 \\
\hline Vertigo pygmaea (Draparnaud) & 1 & 0 \\
\hline \multicolumn{3}{|l|}{ Vitrinidae } \\
\hline Phenacolimax (Gallandia) annularis (Studer) & 5 & 0 \\
\hline Vitrina pellucida (Müller) & 50 & 0 \\
\hline \multicolumn{3}{|l|}{ Zonitidae } \\
\hline Nesovitrea hammonis (Ström) & 5 & 0 \\
\hline Vitrea contracta (Westerlünd) & 4 & 0 \\
\hline Aegopinella nitidula (Draparnaud) & 2 & 0 \\
\hline \multirow{3}{*}{\multicolumn{3}{|c|}{$\begin{array}{l}\text { Subclass PROSOBRANCHIA } \\
\text { Order MESOGASTROPODA }\end{array}$}} \\
\hline & & \\
\hline & & \\
\hline Cochlostoma sp. & 130 & 0 \\
\hline Total & 3568 & 1.98 \\
\hline
\end{tabular}

* Some authors, like Vaught (1989), split the old Helicidae family into Helicidae and Hygromiidae.

The ants collected live were transferred to the laboratory in appropriately labelled polyethylene flasks. They were then kept in artificial anthills until their dissection in the following days. Only a small number of $F$. rufibarbis specimens collected in tetania were kept alive until they died a natural death in order to obtain information on survival.

The ants collected in Redipollos from different plots and in different samplings were anaesthetised and measured. Dissection was under the stereo- microscope examining the head, thorax and abdomen separately in Petri dishes containing a saline solution $(154 \mathrm{mM} \mathrm{NaCl})$. The $D$. dendriticum brainworm and metacercariae found in each ant were extracted and counted. A sample of them was studied 'in vivo' under the optical microscope. The rest of the material was kept in $70 \%$ alcohol.

The helminthological study of the $2085 F$. rufibarbis ants collected in tetania in the flat area was done in the same way. Most metacercariae obtained 


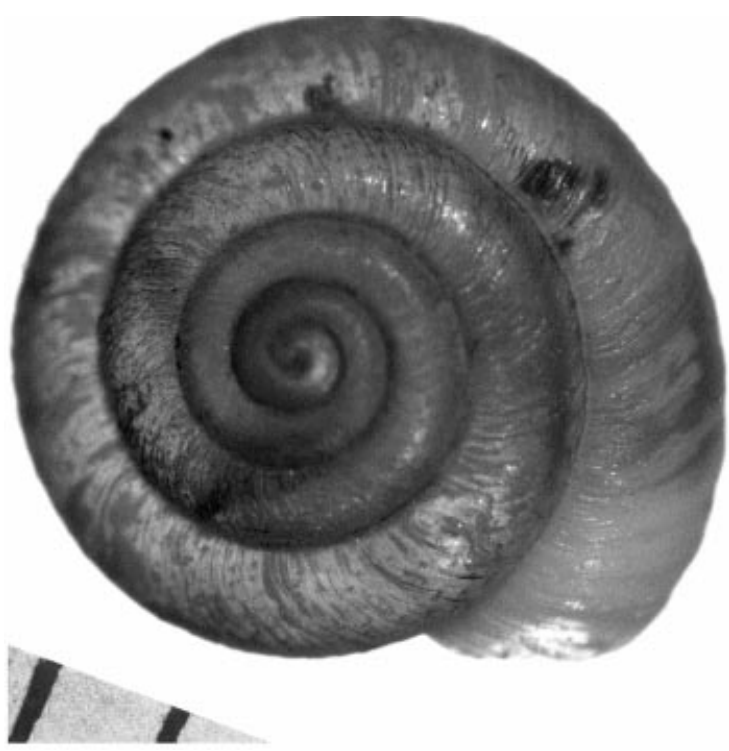

Fig. 1. Helicella corderoi, 1st intermediate host for Dicrocoelium dendriticum. Scale: $1 \mathrm{~mm}$.

were used to infect lambs and hamsters. The rest of the metacercariae and ants were placed in liquid nitrogen to carry out later isoenzymatic analyses, or in $70 \%$ alcohol to carry out morphological studies. In 25 encysted metacercariae extracted from the abdomen the maximum body width and length and the thickness of the cyst wall were measured using an ocular micrometer connected to an optical microscope. In addition, the same measurements were made (except that of the thickness of the cyst wall) of 25 metacercariae excysted in distilled water and then fixed in $70 \%$ alcohol.

In order to characterize $D$. dendriticum metacercariae, isoelectric focusing in thin-layer polyacrylamide gel technique was used, as described in Campo et al. (1998) for D. dendriticum adults. A total of 1608 metacercariae, distributed among samples consisting of 15-185 metacercariae each - all from the abdomen of the same ant-were analysed. The activity of the following enzymes was studied: lactate dehydrogenase (LDH, EC 1.1.1. 27), glucose phosphate isomerase (GPI, EC 5.3.1.9), phosphoglucomutase (PGM, EC 2.7.5.1) and acid phosphatase (AcP, EC 3.1.3.2), in 1608, 924, 1458 and 1608 metacercariae, respectively, extracted from $33 \mathrm{~F}$. rufibarbis ants from 4 sites in the flat area: 13 from Grulleros, 11 from San Cipriano del Condado, 8 from Villafalé and 1 from Valencia de Don Juan. All the enzymatic activity bands observed were considered to interpret the results obtained, but they were differentiated as strong bands (S), weak bands $(\mathrm{W})$ and very weak bands ( $\mathrm{V} \mathrm{W})$.

RESULTS

\section{Molluscs}

Twenty-six species of Gastropoda were found, most of them on pasture on limestone, but infection by $D$. dendriticum was only detected in Helicella $(H$.$) itala$ and H. corderoi (Table 1, Fig. 1). Both species, which were the most abundant, also hosted larval stages of Brachylaimidae spp. (Digenea) and Protostrongylidae spp. (Nematoda), although this paper only includes infection by $D$. dendriticum.

Helicella itala. The abundance of this species was greater in spring, fell in summer and increased again in autumn, although it was still lower than in spring. The young (very young and young) specimens were more abundant in spring whilst the adults were more so in autumn. A more variable situation was observed on considering the data for each zone and habitat in detail. The highest abundance of $H$. itala was detected in zone $\mathrm{B}$, followed by zone $\mathrm{A}$ and in the pasture on limestone habitat. A large number of very young $H$. itala was observed in zone $\mathrm{C}$ in April and May. Specimens of this species were mainly found in pasture areas in spring and sheltering between soil and rock in moss and other plants, principally the Genista hispanica shrub and Eringium campestre thistle, in summer. In autumn a high percentage of specimens were again found on pastureland. Active molluscs were recorded in spring, September and October and molluscs withdrawn into their shells, but without an epiphragm, in every month of the year. Molluscs with an epiphragm were observed, mainly in summer and winter.

D. dendriticum daughter sporocysts were harboured in the hepatopancreas by $2.98 \%$ of a total 2084 specimens of $H$. itala examined (Table 1). As can be seen in Fig. 2 infection was recorded in every month except February. The sampling of February 1989 could not be done because of the bad meteorological conditions (20 days of snow and 12 of frost during the month). The highest prevalence was observed in September. By means of the chi-square test, statistically significant differences were observed among the sampling months with regard to infection prevalence $\left(\chi^{2}=21.903 ; P \leqslant 0.05 ;\right.$ g.l. $=$ $11)$.

Infection prevalence increased with their age and shell diameter (Table 2). Statistically significant differences in the infection prevalence between age groups were observed on using $\chi^{2}$ analysis $\left(\chi^{2}=\right.$ $31.143 ; P \leqslant 0.005 ;$ g.l. $=2)$. On applying the $2 \times 2$ contingency tables statistically significant differences were detected between the young and intermediate, young and adults, intermediate and adults. The highest infection prevalence was detected in the young molluscs in September $(7.69 \%)$ and in the adults in May $(30.43 \%)$.

The examined molluscs from different zones and habitats and their prevalence of infection are summarized in Table 3. By means of $\chi^{2}$ analysis statistically significant differences were observed in the infection prevalence between the pasture on 


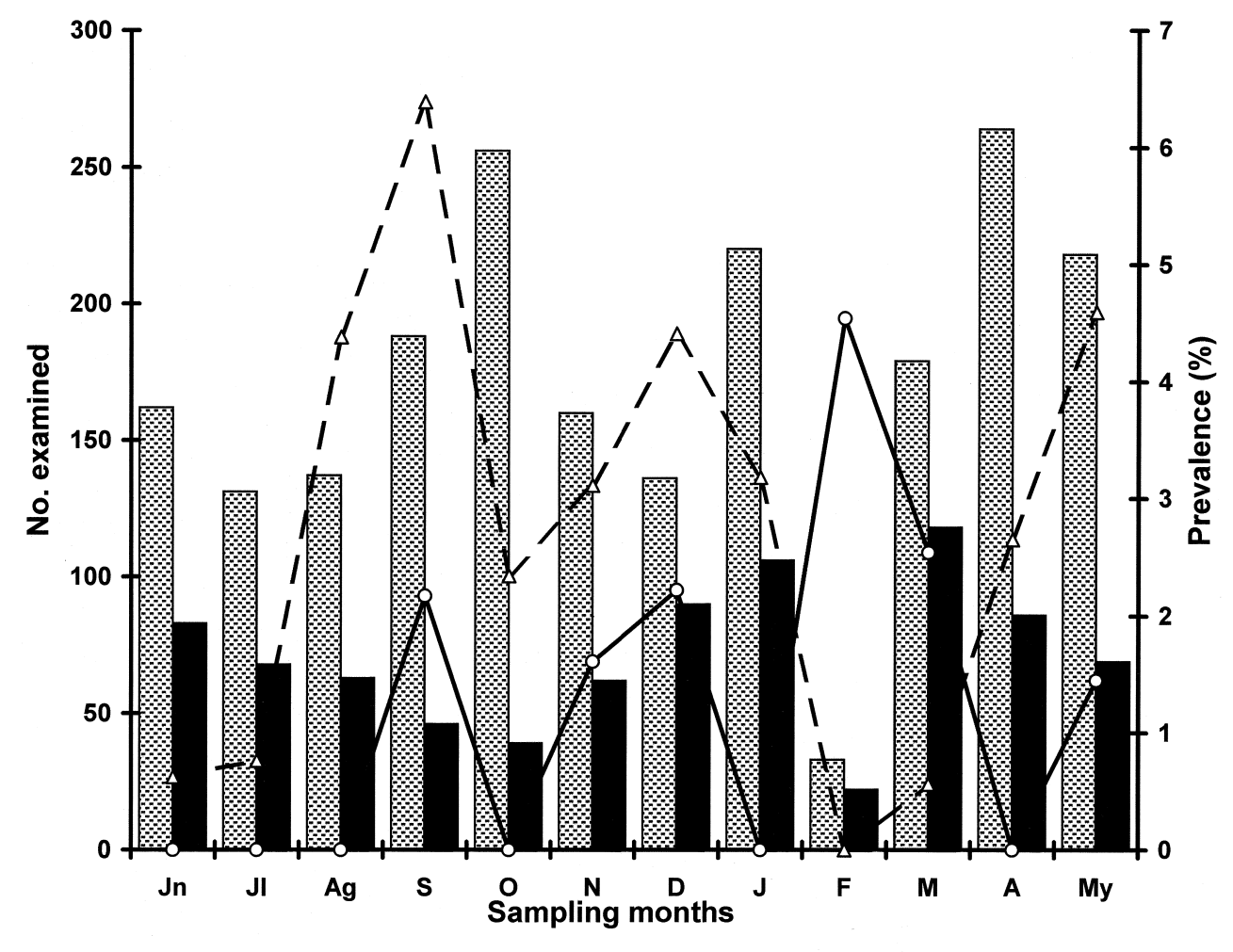

No. H. corderoi $-\Delta-\%$ H. itala $-0-\%$ H. corderoi

Fig. 2. Infection prevalence of Helicella itala and Helicella corderoi by D. dendriticum throughout the sampling period (June, 1987-May, 1989: the data for each month in the 2 years are shown jointly).

Table 2. Infection prevalence of $H$. itala and $H$. corderoi by $D$. dendriticum according to their age and shell diameter (size)

\begin{tabular}{lcllll}
\hline \hline & \multicolumn{2}{l}{ H. itala } & \multicolumn{2}{l}{ H. corderoi } \\
\cline { 2 - 3 } \cline { 5 - 6 } Age/size(mm) & Exam. & Infect. (\%) & & Exam. & Infect. (\%) \\
\hline Young & 786 & $0 \cdot 63$ & & 300 & $0 \cdot 33$ \\
Intermediate & 303 & $2 \cdot 97$ & & 25 & $0 \cdot 00$ \\
Adult & 995 & $4 \cdot 82$ & & 527 & $1 \cdot 72$ \\
Size 2-4 & - & - & & 27 & $0 \cdot 00$ \\
Size 4-6 & - & - & & 481 & $0 \cdot 42$ \\
Size 6-8 & - & - & & 344 & $2 \cdot 03$ \\
Size 3-6 & 29 & $0 \cdot 00$ & & - \\
Size 7-10 & 486 & $0 \cdot 41$ & & - \\
Size 11-14 & 1152 & $2 \cdot 60$ & - & - \\
Size 15-18 & 417 & $7 \cdot 19$ & - & - \\
\hline \hline
\end{tabular}

Exam. = number examined; Infect. $(\%)=\%$ infected.

limestone and pasture-Genista hispanica complex habitats belonging to each zone $\left(\chi^{2}=18.292\right.$; $P \leqslant 0.005 ;$ g.l. $=4)$. On applying the $2 \times 2$ contingency tables statistically significant differences were detected between the pasture $\mathrm{A}$-pasture $\mathrm{B}$; pasture A-Genista C; pasture B-Genista B; pasture B-pasture C; Genista B-Genista C habitats.

The very reduced and concentrated infection at
Table 3. Infection prevalence of $H$. itala by $D$. dendriticum according to the zones and habitats

\begin{tabular}{lrc}
\hline \hline & \multicolumn{2}{c}{ Molluscs } \\
Origin/habitat & Examined & Infected (\%) \\
\hline Zone A & 1172 & $3 \cdot 25$ \\
Zone B & 822 & $2 \cdot 19$ \\
Zone C & 90 & $6 \cdot 77$ \\
Pasture on limestone & 1548 & $2 \cdot 71$ \\
Pasture - Genista hispanica & 536 & $3 \cdot 73$ \\
Zone A/Pasture on limestone & 1172 & $3 \cdot 25$ \\
Zone B/Pasture on limestone & 306 & $0 \cdot 33$ \\
Zone C/Pasture on limestone & 71 & $4 \cdot 17$ \\
Zone B/Pasture - Genista & 516 & $3 \cdot 29$ \\
hispanica & & \\
Zone C/Pasture - Genista & 21 & 15 \\
hispanica & & \\
\hline \hline
\end{tabular}

one or various points of the hepatopancreas corresponded to the presence of daughter sporocysts containing barely evolved germinal masses (Fig. 3), whilst sporocysts with well-developed cercariae were mainly observed in the infection spread throughout the hepatopancreas, even invading other organs (Figs. 4,5,6). However, some molluscs were found with the parasite at different development stages at the same time. The time when the different de- 


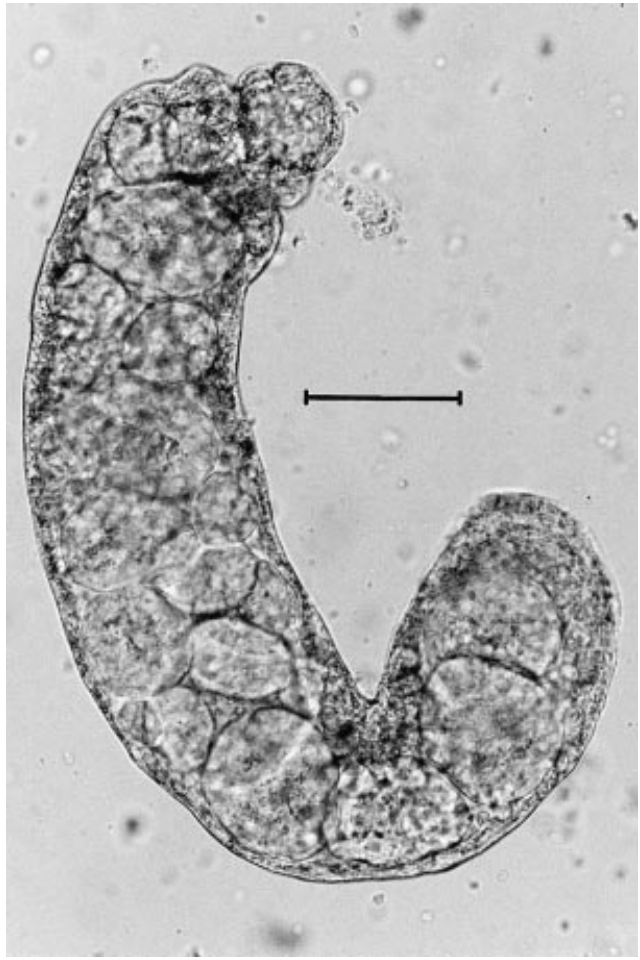

Fig. 3. Dicrocoelium dendriticum daughter sporocyst containing germinal masses. Scale bar: $100 \mu \mathrm{m}$.

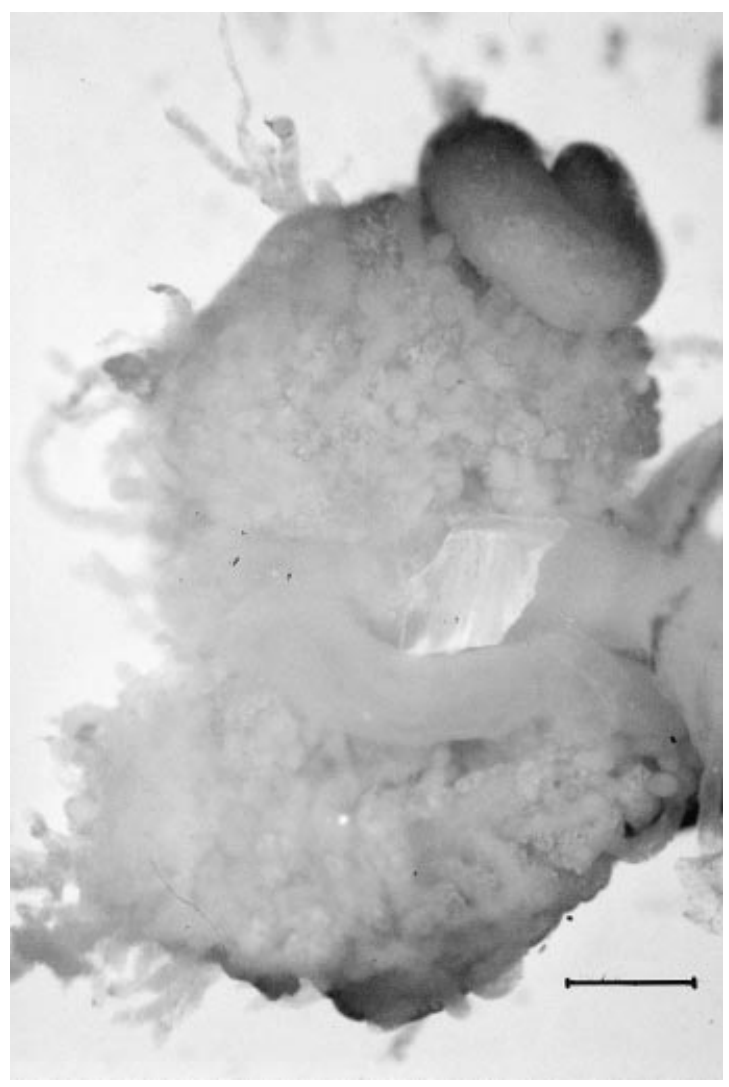

Fig. 4. Helicella itala hepatopancreas with many welldeveloped daughter sporocysts (white sacciform elongated structure) spread throughout the whole hepatopancreas. Scale bar: $1 \mathrm{~mm}$. velopment degrees of the $D$. dendriticum sporocysts were found in the whole study area and the age of the molluscs which harboured them are summarized in Fig. 7. The highest percentage of molluscs containing well-developed cercariae was detected in May and October and that of the one harbouring germinal mass in September.

According to the measurements corresponding to the 1000 daughter sporocysts studied at different stages of development, the length varied between $560 \mu \mathrm{m}$ (in a sporocyst with undifferentiated germinal mass) and $4160 \mu \mathrm{m}$ (in a sporocyst with developed cercariae $)(\overline{\mathrm{x}}=1986 \pm 0.0084 \mathrm{SE})$ and the width between 150 and $501 \mu \mathrm{m}(\overline{\mathrm{x}}=246 \pm 0 \cdot 008)$.

Helicella corderoi. Specimens of this species were collected through the year but the abundance was, in general, greater at the end of autumn and in winter. Adult specimens were clearly predominant in September and November and young ones in May and October. H. cordero $i$ was always more abundant in the pasture on the limestone habitat, and predominantly in Zone $\mathrm{C}$ in September and October, in Zone B in November and December and in Zone A during the rest of the year. Active specimens were found in October, March and April. Molluscs withdrawn into their shells but without an epiphragm were observed in all the months of the year and those with an epiphragm predominated in summer. $H$. cordero $i$ showed a preference for pasture, except in summer, when it chose the soil-rock transition area; in October it left this location to be on limestone and bare soil, seeking out pasture again when the bad weather started.

D. dendriticum daughter sporocysts were found in the hepatopancreas of $1.06 \%$ of the $852 \mathrm{H}$. cordero $i$ specimens examined (Table 1). On considering the whole sampling period, infection was only detected in six months and the highest prevalence was observed in February although a few specimens were examined (Fig. 2).

Prevalence increased with age and shell diameter (Table 2). Only one young $H$. corderoi was seen infected in February. The greatest infection prevalence was detected in the adults in March. Although specimens from the three study zones and the different habitats were examined, infected molluscs were only found from zone A and from pasture on limestone habitats.

The only young $H$. corderoi found infected contained daughter sporocysts with germinal masses, concentrated at one point of the hepatopancreas. Most of the infected adults contained daughter sporocysts with cercariae migrating to different parts of the hepatopancreas. Nevertheless, in one of them collected in May sporocysts with well-developed cercariae invaded all the hepatopancreas and the genital apparatus. Taking into account the measurements carried out on 500 daughter D. dendriticum 


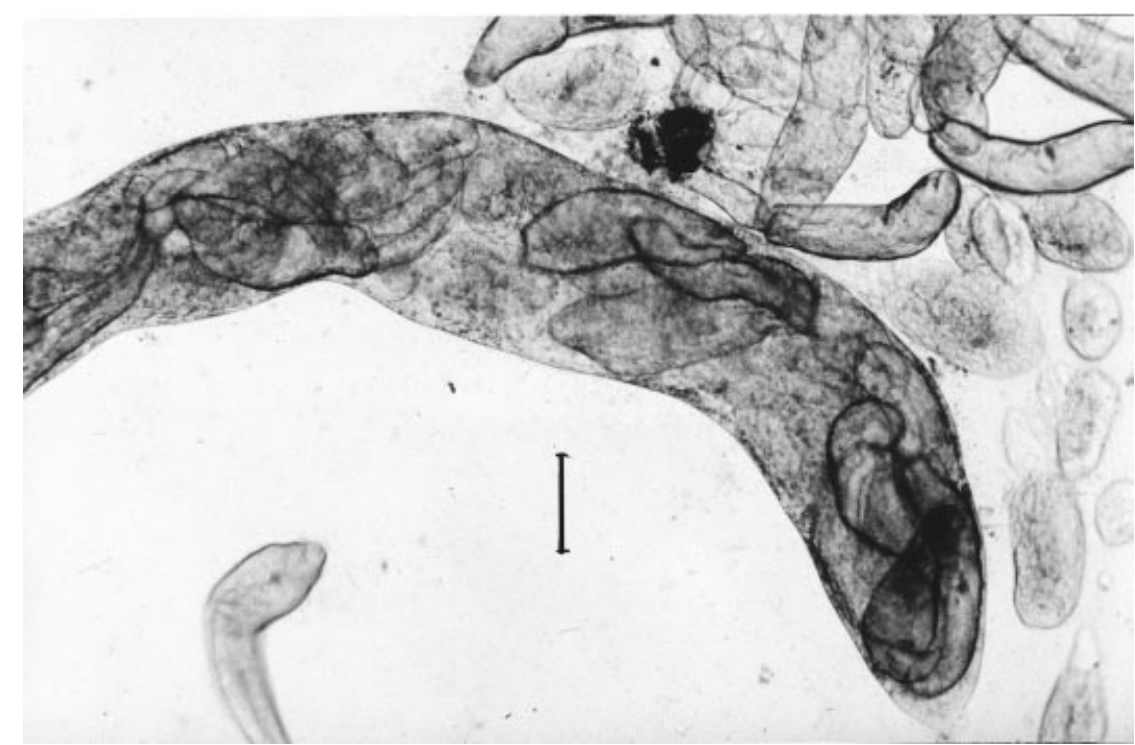

Fig. 5. Dicrocoelium dendriticum daughter sporocyst containing well-developed cercariae and some free cercariae. Scale bar: $150 \mu \mathrm{m}$.

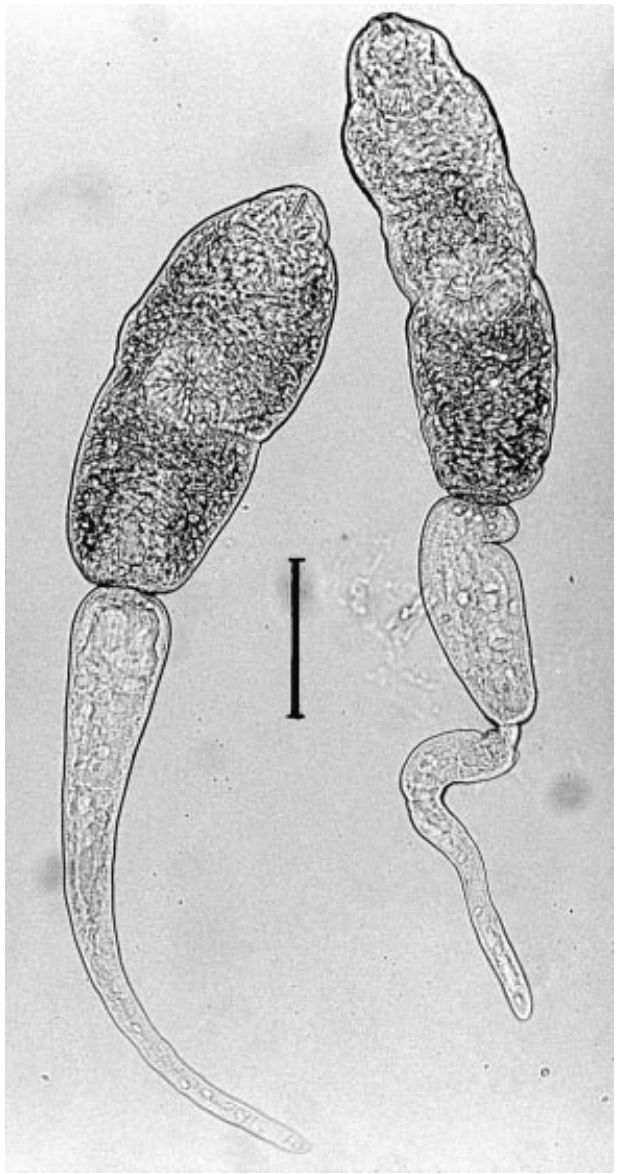

Fig. 6. Dicrocoelium dendriticum cercariae. Scale bar: $100 \mu \mathrm{m}$.

sporocysts, at different stages of development, the length varied between 200 and $1540 \mu \mathrm{m}(\overline{\mathrm{x}}=833 \pm$ $0 \cdot 246 \mathrm{SE})$, and the width between 20 and $170 \mu \mathrm{m}$ $(\overline{\mathrm{x}}=86 \pm 0 \cdot 026)$.
Ants

In the mountain area. The results obtained with tubes placed in the earth were unsatisfactory because both the number of ant species captured and the specimens collected from each was very small. We used 160 traps and ants were only found in 29 of the 80 placed in October, 1988, belonging to the species Formica sanguinea, F. cunicularia and F. pratensis. The maximum number of ants per trap was $12(\overline{\mathrm{x}}=$ 2.59).

In the second sampling type the ants were taken directly from 53 anthills : 23 in zone A, 16 in zone B and 14 in zone C. In this way 24 ant species, all belonging to the family Formicidae were collected (Table 4). These species are grouped by subfamilies according to Collingwood (1978). The helminthological study was carried out on 5993 of the 6555 specimens gathered. As a result we found $D$. dendriticum metacercariae in ants collected between April and November from 14 anthills: 2 Formica cunicularia and $3 F$. pratensis in zone A; $2 F$. rufibarbis in zone B; $3 F$. sanguinea and $4 F$. pratensis in zone $\mathrm{C}$.

The third sampling type allowed us to detect infected ants in tetania in the surroundings of 29 nests: $2 F$. pratensis and $9 F$. rufibarbis (Fig. 8) in May 1990, in zone A; 5 F. rufibarbis in May 1990, 4, 1 and 8 F. pratensis in May 1990, August 1990 and June 1991, respectively, in zone C. The infected ants were found attached to various plants, such as Anthyllis vulneraria, Poterium sanguisorba, Lotus corniculatus, Plantago lanceolata, Genista hispanica and various gramineae species, like Bromus erectus and Festuca rubra, situated in the area surrounding the anthills. The number of workers in tetania observed in each anthill was variable and oscillated 


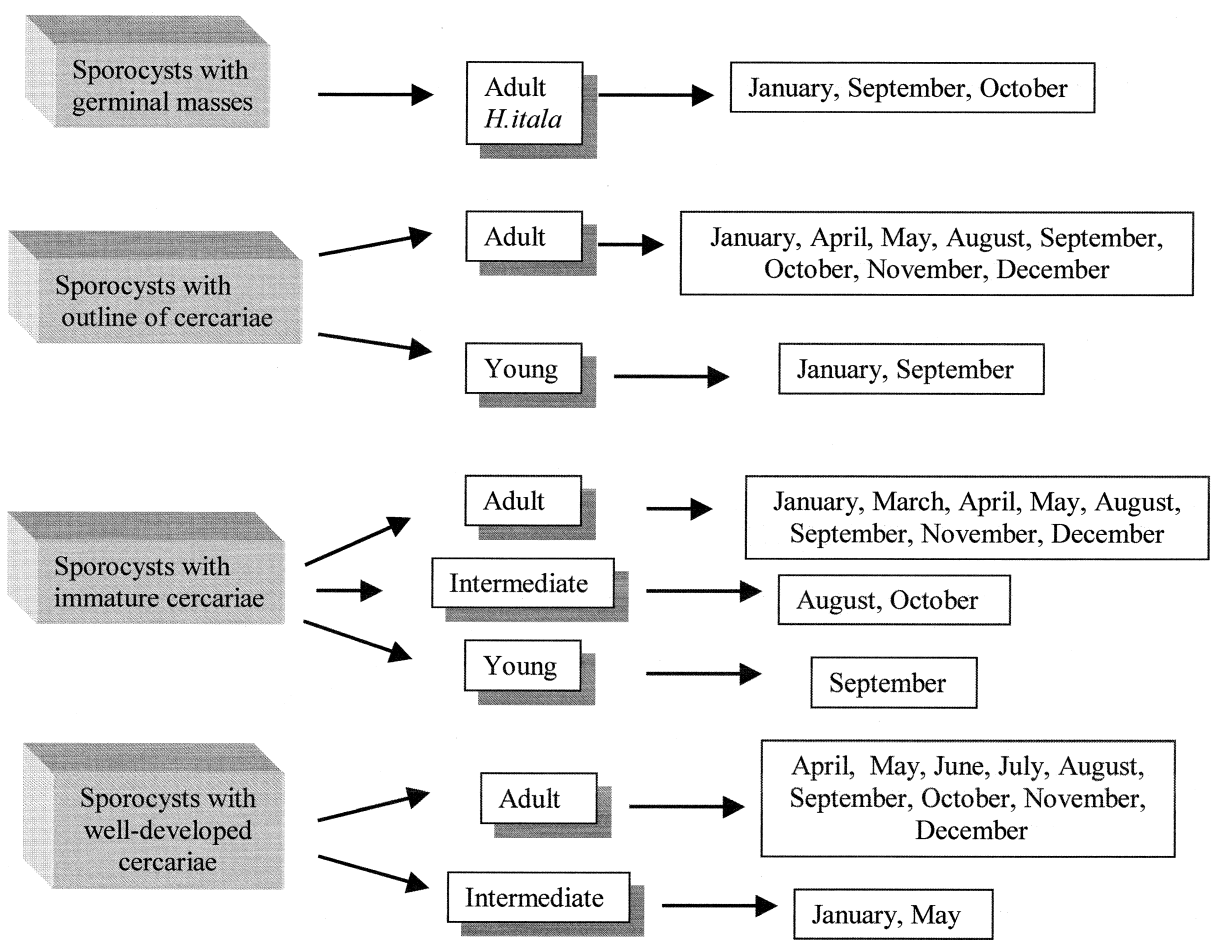

Fig. 7. Schematic diagram of the time in which the different development degrees of Dicrocoelium dendriticum daughter sporocysts were observed in Helicella itala collected in the whole study area.

between 1 and 9 (average 5). The most frequently occurring position for these workers was head down and on plants in the south-eastern part of the anthill. The behaviour of infected $F$. pratensis ants in relation to time and ambient temperature at ground level around some of the anthills examined in zone $\mathrm{C}$ is shown in Fig. 9. Fifty-five of these ants were helminthologically examined.

The $F$. cunicularia, $F$. pratensis, $F$. rufibarbis and $F$. sanguinea infection prevalence and intensity by $D$. dendriticum metacercariae are included in Tables 4 and 5, respectively. In addition, on dissecting various specimens, only one brainworm of the parasite per ant was observed in the suboesophageal ganglion, which was not encysted (Fig. 10). We observed the scars produced by the cercariae on crossing the craw in their flight towards the head, but we did not do a recount.

In the flat area. In the flat area sites close to the town of León active Formica rufibarbis ants were observed between March and November and in tetania from May to October. The ambient temperature (at ground level) at the time of collection, carried out between May and September, oscillated between 16 and $28{ }^{\circ} \mathrm{C}$ and the relative humidity from 64 to $77 \%$. The ants in tetania were found attached to plants of the species Lotus corniculatus, Plantago lanceolata, Taraxacum dens-leonis, Trifolium pratense and Medicago sativa, although mainly in the last one. We managed to collect several dozen ants in tetania from one single $M$. sativa plant, usually attached to the flowers, up to 8 or 10 specimens per flower. It was not necessary to locate the nests of $F$. rufibarbis, which are barely visible, to find the ants infected with $D$. dendriticum attached to the plants. Some of the ants collected in tetania survived in the artificial nests in the laboratory for 6.5 months (from the end of August, 1992 to the middle of March, 1993).

A total of 2085 specimens of $F$. rufibarbis were examined (length $4 \cdot 2-5 \cdot 7 \mathrm{~mm} ; \overline{\mathrm{x}}=4 \cdot 95 \pm 0 \cdot 10$ ) and metacercariae were found in the abdomen (Figs. 11, 12) of $95.39 \%$ of these specimens (Table 4 ). The origin of the ants and the infection percentages were: $1584(95 \cdot 26 \%$ infected) from Villafalé, $369(96 \cdot 20 \%)$ from Grulleros, $28(96.42 \%)$ from Valencia de Don Juan, $27(100 \%)$ from San Cipriano del Condado, 27 $(100 \%)$ from Navatejera, $21 \quad(90.47 \%)$ from Mellanzos, $13(92.30 \%)$ from Villa de Soto, 13 $(84.61 \%)$ from Valdelafuente, $3(66.66 \%)$ from Palanquinos. The number of metacercariae per ant abdomen (Table 5), similar every month, varied between $48 \cdot 31 \pm 2 \cdot 19$ in June and $59 \cdot 77 \pm 1 \cdot 50$ in August. The size of these encysted metacercariae is shown in Table 6 . The length of metacercariae excysted in distilled water was $412 \cdot 80-624 \mu \mathrm{m}(\overline{\mathrm{x}}=$ $510 \cdot 33 \pm 9 \cdot 36)$ and the width from $115 \cdot 20$ to $201 \cdot 60 \mu \mathrm{m}(\overline{\mathrm{x}}=161 \cdot 66 \pm 4 \cdot 40)$.

Metacercaria isoenzymatic determination. To interpret the results obtained by using isoelectric focusing, of $D$. dendriticum metacercariae from $F$. rufibarbis, strong (S), weak (W) and very weak (V W) enzymatic activity bands were considered.

The LDH activity in the $1608 \mathrm{D}$. dendriticum metacercariae analysed was observed in the $\mathrm{pH}$ range 
Table 4. Prevalence of infection by $D$. dendriticum metacercariae in the abdomen of the Formicidae species studied from the mountains, except F. rufibarbis **

\begin{tabular}{|c|c|c|}
\hline Ant species & $\begin{array}{l}\text { Number } \\
\text { examined }\end{array}$ & $\begin{array}{l}\text { Percentage } \\
\text { infected }\end{array}$ \\
\hline \multicolumn{3}{|l|}{ Dolichoderinae } \\
\hline Tapinoma ambiguum Emery & 287 & 0 \\
\hline Tapinoma erraticum (Latreille) & 26 & 0 \\
\hline \multicolumn{3}{|l|}{ Formicinae } \\
\hline Formica cunicularia Latreille & 1158 & $0 \cdot 69$ \\
\hline Formica fusca (Linnaeus) & 68 & 0 \\
\hline Formica polyctena (Förster) & 250 & 0 \\
\hline Formica pratensis Retzius & 2030 & $4 \cdot 33$ \\
\hline Formica pratensis* & 55 & 100 \\
\hline Formica pressilabris (Nylander) & 390 & 0 \\
\hline Formica rufibarbis Fabricius & 288 & $6 \cdot 59$ \\
\hline Formica rufibarbis $* *$ & 2085 & $95 \cdot 39$ \\
\hline Formica sanguinea Latreille & 234 & $1 \cdot 28$ \\
\hline Lasius alienus (Förster) & 150 & 0 \\
\hline Lasius flavus (Frabicius) & 60 & 0 \\
\hline Lasius niger (Linnaeus) & 65 & 0 \\
\hline Lasius umbratus (Nylander) & 31 & 0 \\
\hline Polyergus rufescens Latreille & 5 & 0 \\
\hline Proformica depilis Bondroit & 17 & 0 \\
\hline \multicolumn{3}{|l|}{ Myrmicinae } \\
\hline Aphaenogaster gibbosa (Latreille) & 64 & 0 \\
\hline Leptothorax pardoi Tinaut & 95 & 0 \\
\hline Leptothorax unifasciatus Latreille & 152 & 0 \\
\hline Myrmica sabuleti Meinert & 183 & 0 \\
\hline Myrmica shencki Emery & 4 & 0 \\
\hline Tetramorium caespitum (Linnaeus) & 229 & 0 \\
\hline Tetramorium hispanicum Emery & 5 & 0 \\
\hline Tetramorium impurum (André) & 45 & 0 \\
\hline Tetramorium semilaeve (André) & 157 & 0 \\
\hline Total & 8133 & $20 \cdot 39$ \\
\hline
\end{tabular}

* Collected in tetania.

** Collected in the flat area in tetania.

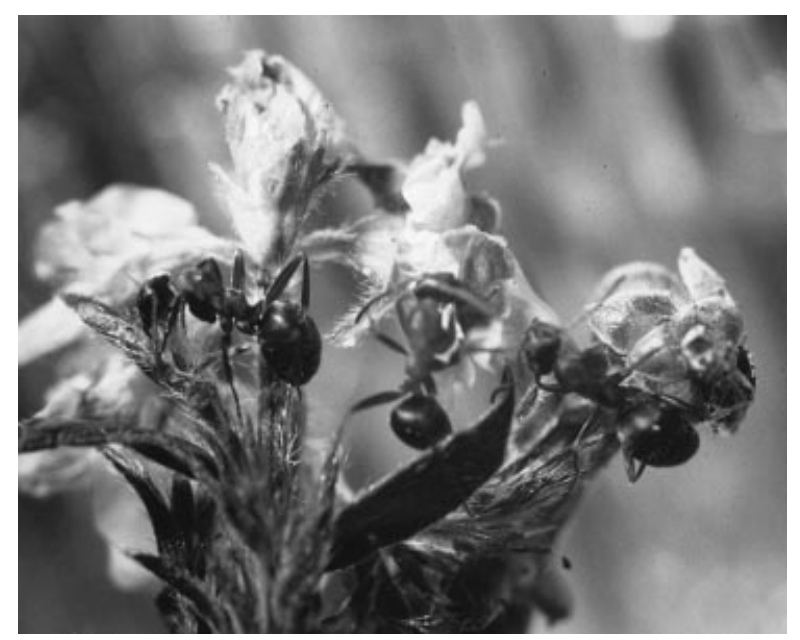

Fig. 8. Infected Formica rufibarbis specimens, 2nd intermediate host for Dicrocoelium dendriticum, in tetania attached to a plant in the field. The real size of the ants is about $5 \mathrm{~mm}$.
6י40-7·13. Four enzymatic types were found designated as: LDH-1 (pH, band intensity : $6 \cdot 40, \mathrm{~W} ; 6 \cdot 60$, $\mathrm{W} ; 6 \cdot 72, \mathrm{~W} ; 6 \cdot 86, \mathrm{~W} ; 7 \cdot 8, \mathrm{~W}), \mathrm{LDH}-2$ (6.60, W; $6 \cdot 72, \mathrm{~W} ; 6 \cdot 86, \mathrm{~W} ; 7 \cdot 08, \mathrm{~V} \mathrm{~W} ; 7 \cdot 13, \mathrm{~W}), \mathrm{LDH}-3$ $(6 \cdot 40, \mathrm{~S} ; 7 \cdot 08, \mathrm{~V} \mathrm{~W})$ and LDH-4 $(6 \cdot 40, \mathrm{~V} \mathrm{~W} ; 6 \cdot 72$, $\mathrm{W} ; 6.86, \mathrm{~V} \mathrm{~W} ; 7.08, \mathrm{~S})$.

On studying the GPI activity 4 enzymatic types were found in $924 \mathrm{D}$. dendriticum metacercariae: GPI-1 (6.27, V W ; 6.43, V W 6.54, S; 6.69, W; 6.80, $\mathrm{V} W ; 6 \cdot 83, \mathrm{~V}$ W $)$, GPI-2 (6.27, V W; 6.43, V W; $6 \cdot 54, \mathrm{~S} ; 6 \cdot 72, \mathrm{~S} ; 6 \cdot 80 \mathrm{~S}), \mathrm{GPI}-3(6 \cdot 54, \mathrm{~S} ; 6 \cdot 72, \mathrm{~V}$ W; $6 \cdot 80, \mathrm{VW})$ and GPI-4 $(6 \cdot 54, \mathrm{~W} ; 6 \cdot 72, \mathrm{~W} ; 6 \cdot 80, \mathrm{~W})$. The activity bands were in a $\mathrm{pH}$ range between $6 \cdot 27$ and $6 \cdot 83$.

The PGM activity on analysing $1458 D$. dendriticum metacercariae was detected in a $\mathrm{pH}$ range $6 \cdot 20-6 \cdot 60$. Two enzymatic models were observed: PGM-1 $(6 \cdot 20, \mathrm{~V}$ W $6 \cdot 60, \mathrm{~S})$ and PGM-2 $(6 \cdot 20, \mathrm{~S} ; 6 \cdot 40, \mathrm{~S})$ 

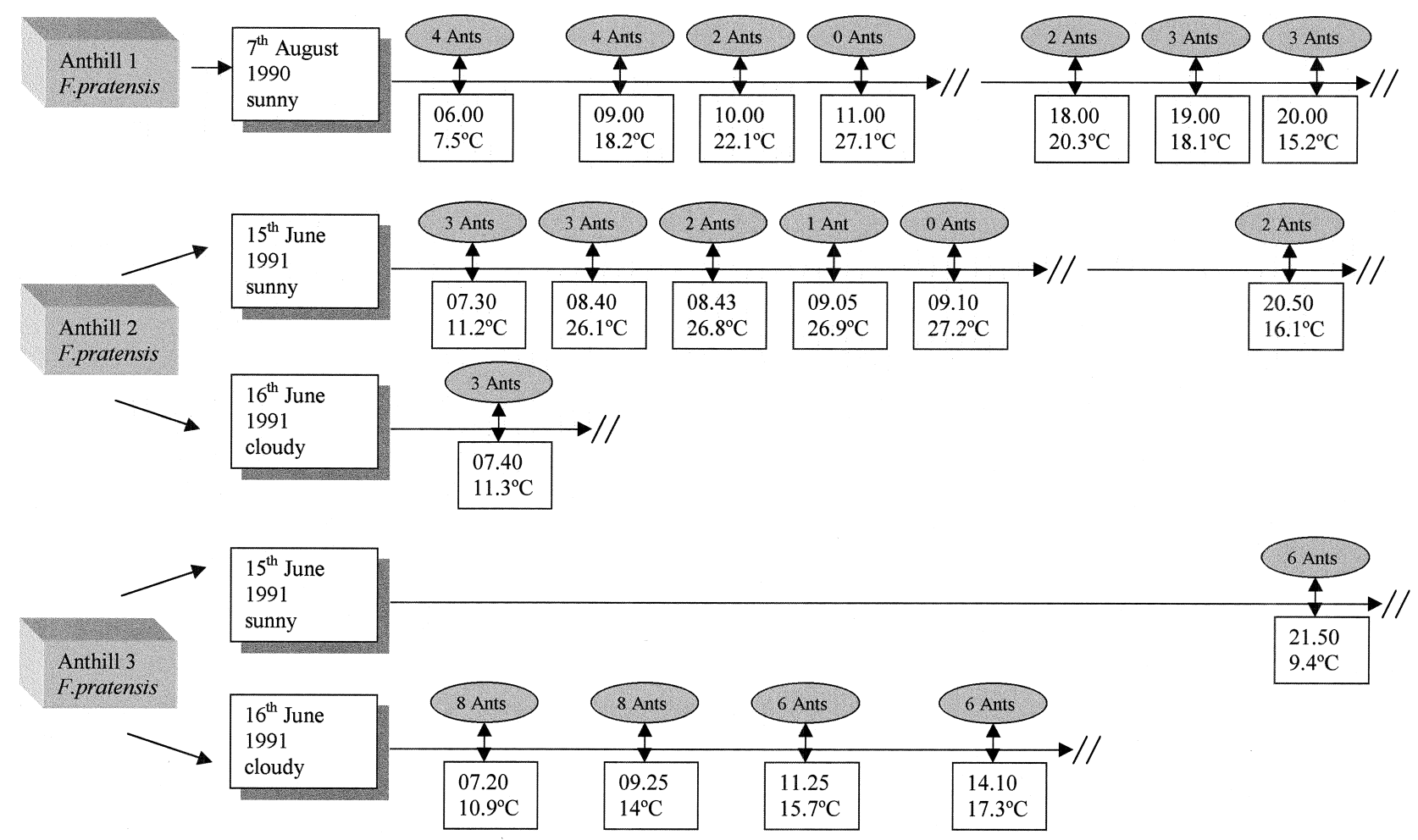

Fig. 9. Schematic diagram of the number of ants in tetania in relation to the time of day and ambient temperature at ground level.

On examining $1608 \mathrm{D}$. dendriticum metacercariae AcP activity was detected between pH 5.86-5.92. Although the bands observed are diffuse, 4 enzymatic models could be identified: AcP-1 $(5 \cdot 86, \mathrm{~V}$ $\mathrm{W} ; 5.91, \mathrm{~S} ; 5.92, \mathrm{~S}), \mathrm{AcP}-2$ (5.92, S), AcP-3 (5.91, V $\mathrm{W} ; 5.92, \mathrm{~V} \mathrm{~W})$ and AcP-4 (5.91, S).

In the enzymatic systems studied different models were generally observed in metacercariae extracted from the same ant, from ants originating from different locations and, sometimes, from those collected in the same place.

\section{DISCUSSION}

\section{Molluscs}

According to our results (Table 1), H. itala and $H$. corderoi are the species responsible for $D$. dendriticum transmission in the study area. Nevertheless, the importance of $H$. itala in dicrocoeliosis epidemiology is greater for being more widely distributed and more abundant, not only in the study area but also in the whole of León province, northern Spain and west and central Europe, while H. corderoi is an endemic species in the mountain area of León province. Moreover the size of $H$. itala specimens is bigger so they could harbour more parasites. The description of both species and different data on their distribution, biology and ecology are recorded in Manga-González (1983).

From our observations it seems that $H$. itala and $H$. corderoi abundance is conditioned by the existence of appropriate temperature and relative hu- midity values, as occurs in spring and autumn, although temperature is a more limiting factor than humidity during the rest of the year. The temperature-humidity binomial has a great influence on mollusc abundance for most authors (Staikou, Lazaridou-Dimitriadou \& Kattoulas, 1989, amongst others).

Our results concerning the highest abundance of $H$. itala adults in autumn and young ones in spring coincides with the observations of Manga-González $(1983,1987)$ and Schuster (1993) in H. itala and $H$. obvia, respectively. Although it is difficult to establish a $H$. corderoi development pattern with the results we obtained, the predominance of adult specimens in November coincides with the observations of Manga-González (1983) for this species in the upper Torio basin (León province, Spain). Ortiz de Zárate (1950) stated that Helicella species are annual and generally do not develop completely until autumn.

Locomotor activity in land pulmonates depends on various external environmental factors, such as light intensity, relative humidity, temperature, soil moisture and time of day. Moreover, endogenous circadian rhythmicity in locomotor activity has been demonstrated (Riddle, 1983). From our results it seems that $H$. itala and $H$. corderoi activity is influenced by temperature and relative humidity at the same time, and the formation of the epiphragm in $H$. corderoi is mainly conditioned by high temperatures and low precipitation, whilst low temperatures also have an influence in the case of $H$. 
Table 5. Comparison of the infection intensity by $D$. dendriticum metacercariae reported here in the ants and those mentioned by other authors

\begin{tabular}{|c|c|c|c|}
\hline Authors & Ant species & Infection range & Intensity $\bar{x} \pm$ s. e. \\
\hline \multirow[t]{5}{*}{ Own observations } & Formica cunicularia & $2-56$ & $26 \cdot 0 \pm 15 \cdot 89$ \\
\hline & $F$. pratensis & $1-186$ & $97 \cdot 5 \pm 20 \cdot 80$ \\
\hline & F. rufibarbis* & $2-107$ & $28 \cdot 3 \pm 7 \cdot 90$ \\
\hline & F. rufibarbis** & $1-240$ & $56.4 \pm 0.93$ \\
\hline & $F$. sanguinea & $2-63$ & $42 \cdot 0 \pm 20 \cdot 00$ \\
\hline Krull \& Mapes (1953) & F. fusca & $6-128$ & -- \\
\hline Klesov \& Popova (1958) & $F$. pratensis & - & 251 \\
\hline Hohorst (1962) & F. cunicularia & - & $>300$ \\
\hline \multirow{3}{*}{ Del Río (1967 } & $F$. pratensis & $1-67$ & 22 \\
\hline & F. rufibarbis &, & , \\
\hline & $F$. sanguinea & , & , \\
\hline \multirow[t]{2}{*}{ Denev et al. (1970) } & F. fusca & $1-580$ & - \\
\hline & $F$. pratensis & 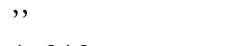 & - \\
\hline \multirow[t]{3}{*}{ Jonlija et al. (1972) } & $F$. lugubris & $1-212$ & - \\
\hline & $F$. pratensis & , & - \\
\hline & $F$. polyctena & 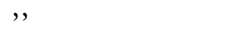 & - \\
\hline \multirow[t]{2}{*}{ Badie et al. (1973) } & $F$. cunicularia & $2-300$ & - \\
\hline & $F$. nigricans $^{* * *} *$ &, & - \\
\hline Srivastava (1975) & $F$. pratensis & $176-443$ & - \\
\hline Kalkan (1976) & F. rufibarbis & $1-117$ & - \\
\hline \multirow[t]{2}{*}{ Paraschivescu (1976) } & F. cunicularia & $11-173$ & - \\
\hline & $F$. pratensis & , & - \\
\hline Paraschivescu et al. (1976) & $F$. pratensis & $5-165$ & - \\
\hline \multirow[t]{3}{*}{ Angelovski \& Iliev (1978) } & Cataglyphus bicolor $\boldsymbol{\wedge}$ & $5-155$ & - \\
\hline & F. rufibarbis & ” & - \\
\hline & F. cunicularia & , & - \\
\hline \multirow[t]{2}{*}{ Badie (1979) } & F. cunicularia & - & $>200$ \\
\hline & $F$. nigricans $^{* * *} *$ & - & \\
\hline \multirow[t]{4}{*}{ Paraschivescu (1981a) } & $F$. cunicularia & $21-31$ & - \\
\hline & F. sanguinea & $2-87$ & - \\
\hline & $F$. pratensis & $11-173$ & - \\
\hline & $F$. fusca & $6-329$ & - \\
\hline Spindler et al. (1986) & $F$. polyctena & $1-53$ & - \\
\hline \multirow[t]{2}{*}{ Schuster (1991) } & F. rufibarbis & $2-127$ & 38 \\
\hline & $F$. pratensis & $2-313$ & 76 \\
\hline
\end{tabular}

* Collected in the mountains; $* *$ collected in the flat area; $* * *=F$. pratensis according to Seifert $(1992) ;{ }^{\boldsymbol{\Delta}}=$ Cataglyphis; $"=$ Figures given for all species without specification.

itala. Bonavita (1961) stated that the formation of an epiphragm is due to a combination of different environmental temperature and relative humidity values. The presence of this temporary structure, observed by us mainly in winter and summer in $H$. itala and in summer in $H$. corderoi, is important for the epidemiology of dicrocoeliosis as it means that the molluscs do not eat the parasite eggs. Nevertheless, active molluscs or those withdrawn into their shells but without an epiphragm, were detected in every month of the year.

Specimens of $H$. itala were mainly found in pasture areas in spring and sheltering between soil and rock in moss and other plants, principally the Genista hispanica shrub and Eryngium campestre thistle, in summer. The preference of $H$. itala for Eryngium campestre in summer was also mentioned by Engel (1957). In autumn a high percentage of specimens was again found on pastureland. Wolda, Zweep \& Schuitema (1971) stated this could indicate the beginning of the search for a place to hibernate, as grazing land provides favourable sheltering areas in winter; Schuster (1993) also recorded this migration. Riddle (1983) mentioned that the slugs and some land snails occupy fairly protected habitats in which daily and seasonal extremes in air temperature are largely avoided.

When we compared the percentage of infection by $D$. dendriticum obtained by us in H. itala $(2.98 \%)$ and in $H$. corderoi $(1.06 \%)$ with those given by other authors in different species of molluscs and countries (Table 7), great variability could be observed. If we focus only on $H$. itala our percentage was lower than those obtained by Del Rio (1967), Tarry (1969) and Manga-González $(1987,1992)$ and higher than those given by Rozman, Jonlija \& Mustapic (1971) and Rozman, Gradjanin \& Cankovic (1974). The infection prevalence of $H$. cordero $i$ was lower than that obtained for H. itala in this study and considerably below that obtained by Manga-González (1992) studying $H$. cordero $i$ from various mountain areas in León province (Spain). Nevertheless, we must point 


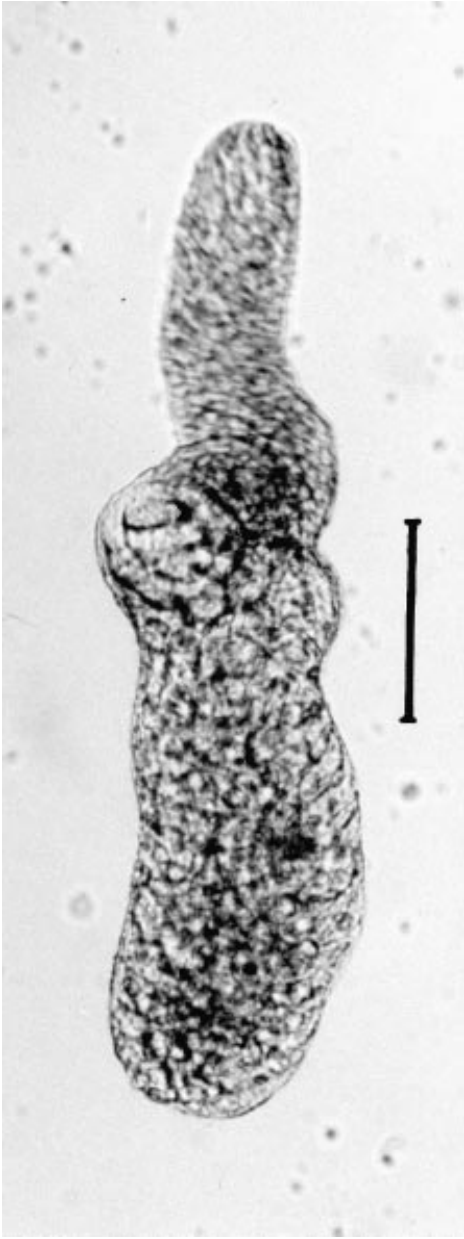

Fig. 10. Dicrocoelium dendriticum brainworm extracted from the Formica pratensis suboesophageal ganglion. Scale bar: $100 \mu \mathrm{m}$.

out that the infection prevalence in both species of molluscs could be higher because according to experimental laboratory studies (González-Lanza et al., 1997) the infection is not visible under the stereomicroscope until at least 50 days post-infection. Moreover, in experimental studies carried out under controlled field conditions (unpublished research) the minimum period for detecting the parasite under the stereomicroscope varied between 2 and 9 months p.i. depending on the infection month.

According to our results (Fig. 2) the highest prevalence for H. itala was obtained in September, May and December, while it was in February and March for H. corderoi. This species seem to be very well adapted to the low temperatures. Nevertheless, it is very risky to establish a $D$. dendriticum transmission model through this species due to the low number of infected specimens found and also due to the lack of publications that could help to interpret our data. There is no unanimity amongst the authors about the dynamics of the mollusc infection, probably due to the different species studied and also the different environmental conditions. So Dementev \& Karabaev (1968) recorded the highest infection prevalence in May

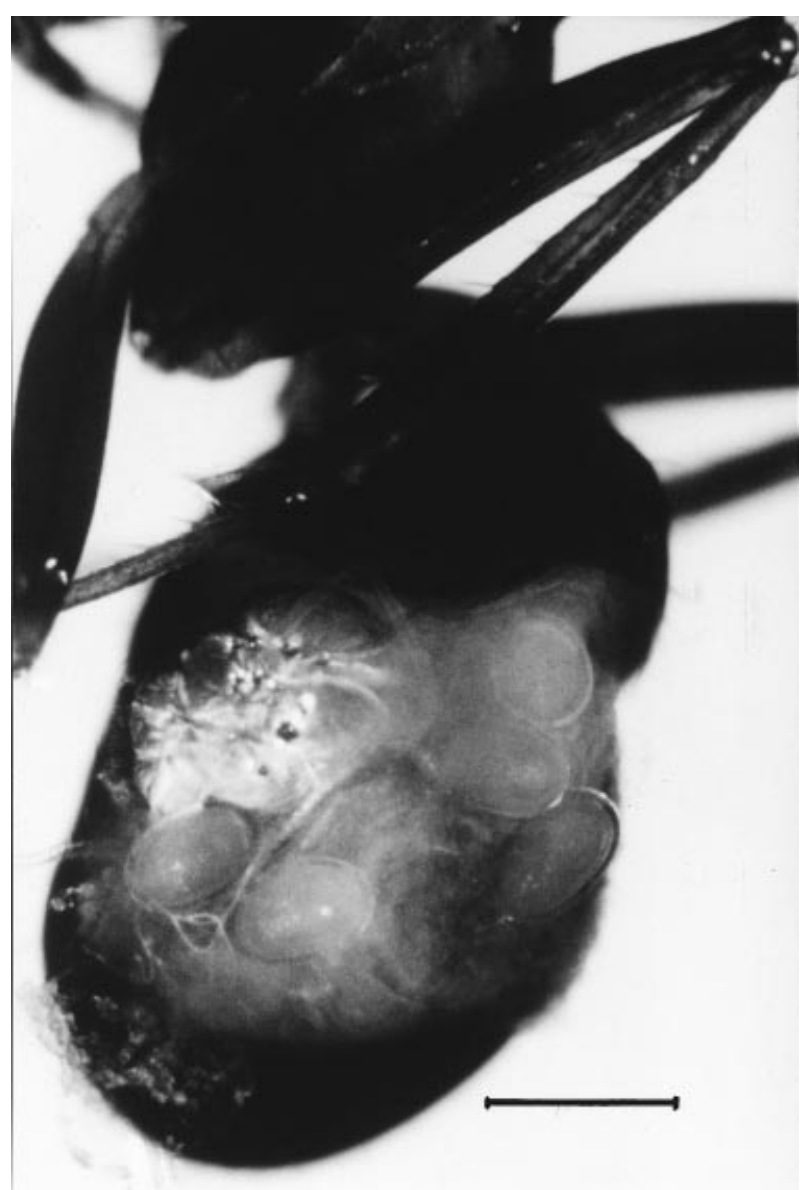

Fig. 11. Dicrocoelium dendriticum metacercariae specimens inside the Formica rufibarbis open abdomen. Scale bar: $400 \mu \mathrm{m}$.

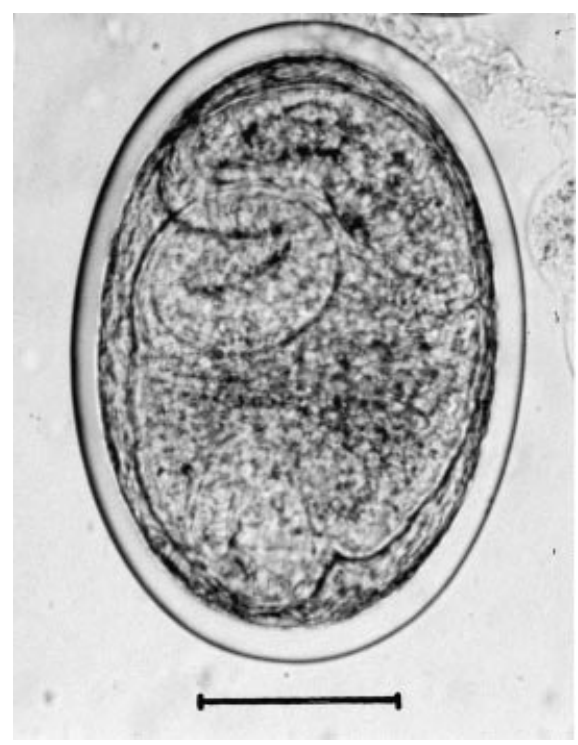

Fig. 12. Dicrocoelium dendriticum metacercaria extracted from the Formica sanguinea abdomen. Scale bar: $100 \mu \mathrm{m}$.

and the lowest in September in Kazakhstan; Kalkan (1970) obtained the highest prevalence in summer and autumn in Turkey; Kuz'movich \& Kostinik (1975) gave an almost constant infection rate 
Table 6. Size of $D$. dendriticum encysted metacercariae obtained from the ant abdomen reported here and by other authors

\begin{tabular}{|c|c|c|c|c|}
\hline \multirow[b]{2}{*}{ Authors } & \multirow[b]{2}{*}{ Ant species } & \multicolumn{3}{|c|}{ D. dendriticum encysted metacercaria size $(\mu \mathrm{m})$} \\
\hline & & Length & Width & Cyst wall thickness \\
\hline Own observations & Formica rufibarbis & $336-461(380)$ & $240-369(283)$ & $5-12(9)$ \\
\hline Krull \& Mapes (1952) & $F$. fusca & $325-465$ & - & $10-40$ \\
\hline \multirow[t]{3}{*}{ Groschaft (1961) } & F. fusca glebaria* & $288-440$ & $192-328$ & - \\
\hline & $F$. pratensis & , & ", & - \\
\hline & F. sanguinea & , & , & - \\
\hline \multirow[t]{2}{*}{ Fromunda et al. (1965) } & F. glebaria* & $185-306$ & $146-204$ & $48-50$ \\
\hline & F. nigricans $* *$ & $148-250$ & $92-111$ & , \\
\hline \multirow[t]{3}{*}{ Del Rio (1967) } & F. pratensis & $280-320(298)$ & $150-210(181)$ & $15-22(19)$ \\
\hline & F. rufibarbis & $371-424(404)$ & $260-310(288)$ & $19-37(25)$ \\
\hline & F. sanguinea & $380-430(408)$ & $267-310(288)$ & $19-38(24)$ \\
\hline Odening (1969) & F. rufibarbis fuscorufibarbis & $243-400(365)$ & $200-270(250)$ & $16-23(20)$ \\
\hline Fromunda et al. (1973) & F. cunicularia & $172-579$ & $91-321$ & $5 \cdot 4$ \\
\hline Kalkan (1976) & F. rufibarbis & $368-448$ & $288-336$ & $80-96$ \\
\hline Paraschivescu et al. (1976) & $F$. pratensis & $174-572$ & $90-320$ & $5 \cdot 4$ \\
\hline \multirow[t]{3}{*}{ Angelovski \& Iliev (1978) } & Cataglyphus bicolor $\boldsymbol{\Lambda}$ & $240-440$ & $280-330$ & 20 \\
\hline & F. fusca & $\bar{l}$ & $\bar{l}$ & 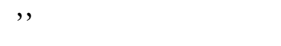 \\
\hline & F. rufibarbis & ,' &, & , \\
\hline Paraschivescu (1981a) & $F$. pratensis & $481-579$ & $260-311$ & - \\
\hline
\end{tabular}

$*=$ Formica cunicularia $; * *=$ Formica pratensis according to Seifert $(1992) ; \boldsymbol{\Lambda}=$ Cataghyphis; $"$ = Figures given for all species without specification.

throughout the year in Ukraine; Manga-González (1987) observed the highest prevalence in October, December and May in Spain and Schuster \& Neumann (1988) found the highest infection prevalence in spring and the lowest in summer with it increasing again in autumn in Germany.

Infection prevalence increased with the age and size of the molluscs (Table 3), a tendency that had already been observed in field (Manga-González, 1987 and Schuster, 1993) and experimental conditions (Alunda \& Rojo, 1983). The highest $H$. itala infection prevalence was detected in the young molluscs in September and in the adults in May. These results partially coincide with those obtained by Manga-González (1987), who recorded the highest infection rate for young of $H$. itala in October and that for adults in October and May.

On taking our results into account, it seems that the infection rate (Fig. 2) and the degree of development (Fig. 7) of the sporocysts which $H$. itala hosts did not follow any clear pattern throughout the year or in the different zones and orientations. This could be due to the fact that viable egg ingestion by the molluscs is related to the time in which contamination of the pastures takes place. So, Zone A was grazed by animals between December and April, thus the pasture was contaminated by parasite eggs then. Contamination favours infection of the molluscs as soon as they become active in spring, with a consequent higher infection rate in September, since several months must pass before the infection becomes visible under the stereo- microscope, as previously mentioned. In contrast, livestock graze in zone $\mathrm{C}$ between April and December, so pasture contamination and mollusc infection must occur during that period, which explains the infection detected in the adult specimens in the following spring. In zone B livestock graze practically throughout the year, so contamination is continuous, since animals eliminate the eggs uninterruptedly (Manga-González et al. 1991; González-Lanza, Manga-González \& Del-Pozo, 1993), although the period of greatest elimination is detected in autumn and, above all, in winter. This meant that infected molluscs were found in almost every month of the year. The exact date when the molluscs were infected is difficult to estimate, but we believe that all the molluscs found infected from the beginning of the year until the end of spring were infected the previous year, although at different times according to the degree of development observed in the parasites. The molluscs that harboured scarcely developed sporocysts from the end of summer until December must have been infected in spring or at the beginning of summer, while those containing sporocysts with well-developed cercariae in the same period could be infected at the beginning of spring or even in the previous year.

The fact that sometimes different developmental stages of the parasites were found in a mollusc at the same time - as had already been observed by Del Rio (1967) and Manga-González (1987) in naturally infected specimens and by González-Lanza et al. (1997) in experimentally infected ones - seems to 
Table 7. Infection prevalence of some Stylommatophora molluscs by $D$. dendriticum obtained by various authors

\begin{tabular}{|c|c|c|c|}
\hline Mollusc species & Prevalence $(\%)$ & Country & Authors \\
\hline \multicolumn{4}{|l|}{ Bradybaenidae } \\
\hline Bradybaena alma-atini & $7 \cdot 4-0 \cdot 9$ & Kazakhstan & Dementev \& Karabaev (1968) \\
\hline B. lantzi & $6 \cdot 4$ & Kazakhstan & Dementev (1968) \\
\hline B. plectotropis var. phaeozona & $3 \cdot 2$ & Kazakhstan & Dementev (1968) \\
\hline B. rubens & $0 \cdot 6$ & Kazakhstan & Dementev (1968) \\
\hline B. semenovi & $1 \cdot 9$ & Kazakhstan & Dementev (1968) \\
\hline Eulota maacki (1) & 28 & Russia & Ovcharenko (1964) \\
\hline \multicolumn{4}{|l|}{ Clausiliidae } \\
\hline Clausilia bidentata & $1 \cdot 5$ & Germany & Schmidt (1967) \\
\hline Laciniaria varnensis & $21 \cdot 4$ & Bulgaria & Denev et al. (1970) \\
\hline \multicolumn{4}{|l|}{ Cochlicopidae } \\
\hline Cionella lubrica (2) & 28 & USA & Mapes (1951) \\
\hline C. lubrica & $5-20$ & Spain & Del Río (1967) \\
\hline C. lubrica & 10 & France & Badie (1979) \\
\hline \multicolumn{4}{|l|}{ Buliminidae } \\
\hline Chondrula microtraga & $23 \cdot 3$ & Bulgaria & Denev et al. (1970) \\
\hline C. tridens & $16 \cdot 5$ & Bulgaria & Denev et al. (1970) \\
\hline Faminia tridens (3) & $5 \cdot 6$ & Bosnia-Herzegovina & Jonlija et al. (1973) \\
\hline F. potaniniana & $0 \cdot 7$ & Kazakhstan & Dementev (1968) \\
\hline Zebrina detrita & $20 \cdot 5$ & Bulgaria & Denev et al. (1970) \\
\hline Z. detrita & $5 \cdot 6$ & Bosnia-Herzegovina & Jonlija et al. (1973) \\
\hline Z. hohenackeri (4) & 62 & Caucasus & Bocharova (1983) \\
\hline \multicolumn{4}{|l|}{ Helicidae* } \\
\hline Cepaea nemoralis & $5 \cdot 6$ & Bosnia-Herzegovina & Jonlija et al. (1973) \\
\hline C. nemoralis & $0 \cdot 72$ & Spain & Manga-González (1992) \\
\hline C. vindobonensis & $5 \cdot 6$ & Bosnia-Herzegovina & Jonlija et al. (1973) \\
\hline \multicolumn{4}{|l|}{ Hygromiidae } \\
\hline Cernuella $(C$.$) virgata$ & $1 \cdot 36$ & Spain & Manga-González (1992) \\
\hline C. virgata & $1 \cdot 0$ & Turkey & Kalkan (1970) \\
\hline C. (Microxeromagna) vestita & $5 \cdot 17$ & Spain & Manga-González (1992) \\
\hline C. (Xeromagna) cespitum arigonis & $2 \cdot 77$ & Spain & Manga-González (1992) \\
\hline Cochlicella acuta & $2 \cdot 1$ & France & Badie \& Rondelaud (1987) \\
\hline C. barbara & 20 & Spain & Manga-González (1992) \\
\hline C. ventricosa $(5)$ & $0 \cdot 5$ & France & Badie \& Rondelaud (1987) \\
\hline Helicella $(H$.$) candicans$ & $4 \cdot 3$ & Turkey & Kalkan (1970) \\
\hline H. corderoi & $7 \cdot 84$ & Spain & Manga-González (1992) \\
\hline H. itala & 50 & Spain & Del Río (1967) \\
\hline H. itala & $6 \cdot 02$ & $\mathrm{U} . \mathrm{K}$ & Tarry (1969) \\
\hline H. itala & $0 \cdot 05$ & Bosnia-Herzegovina & Rozman et al. (1974) \\
\hline H. itala & $5 \cdot 68$ & Spain & Manga-González $(1987,1992)$ \\
\hline H. jamuzensis & 1.03 & Spain & Manga-González (1992) \\
\hline H. madritensis & $1 \cdot 86$ & Spain & Manga-González (1992) \\
\hline H. (H.) obvia & $4 \cdot 30$ & Turkey & Kalkan (1970) \\
\hline H. obvia & $4 \cdot 3$ & Bulgaria & Denev et al. (1970) \\
\hline H. obvia & $20 \cdot 67$ & Germany & Schuster (1992) \\
\hline H. ordunensis & $2 \cdot 13$ & Spain & Manga-González (1992) \\
\hline Helicopsis krynickii $(7)$ & $2 \cdot 6$ & Turkey & Kalkan (1970) \\
\hline H. (Xeropicta) derbentina (6) & $4 \cdot 0$ & Turkey & Kalkan (1970) \\
\hline Monacha carthusiana (8) & $1 \cdot 0$ & Turkey & Kalkan (1970) \\
\hline$M .(M$.$) cartusiana$ & $2 \cdot 39$ & Spain & Manga-González (1992) \\
\hline Theba carthusiana (8) & $1 \cdot 5$ & Bulgaria & Denev et al. (1970) \\
\hline \multicolumn{4}{|l|}{ Zonitidae } \\
\hline Aegopis acies & $1 \cdot 47$ & Bosnia-Herzegovina & Rozman et al. (1974) \\
\hline
\end{tabular}

(1)=Bradybaena maacki; (2)=Cochlicopa lubrica; $(3)=$ Chondrula tridens; $(4)=$ Napaeopsis hohenackeri; $\quad$ (5)= Cochlicella barbara; $(6)=$ Xeropicta derbentina; $(7)=$ Xeropicta krynickii $;(8)=$ Monacha $(M$.) cartusiana. $*$ See the explanation given in Table 1.

indicate that either the mollusc was infected at a different time or that larval development of eggs ingested at the same time is diachronic.

Molluscs containing sporocysts with well-developed cercariae were found throughout nearly the whole year (Fig. 7), although the highest percentages were detected in May and October. The highest values of these percentages were observed in April and October by Tverdokhlebov (1970), in winter and spring by Manga-González (1987) and in spring 
Table 8. Infection prevalence of some Formicidae ants by $D$. dendriticum metacercariae obtained by various authors

\begin{tabular}{|c|c|c|c|}
\hline Ant species & Prevalence $(\%)$ & Country & Authors \\
\hline \multicolumn{4}{|l|}{ Formicinae } \\
\hline Cataglyphis aenescens & $2 \cdot 4-1 \cdot 82$ & Russia & Urazbaev (1979) \\
\hline Cataglyphus bicolor (1) & $0 \cdot 37$ & Macedonia & Angelovski \& Iliev (1978) \\
\hline Formica cinerea & $3 \cdot 21$ & Central Caucasus & Popov \& Kalitina (1962) \\
\hline F. fusca & 31 & USA & Krull \& Mapes (1953) \\
\hline F. fusca & $0 \cdot 8-18$ & Russia & Vershinin (1957) \\
\hline F. fusca & $0 \cdot 71-11 \cdot 11$ & Bulgaria & Veselinov (1962) \\
\hline F. fusca & $3-9$ & Bulgaria & Denev et al. (1970) \\
\hline$F$. fusca & $0 \cdot 24$ & Macedonia & Angelovski \& Iliev (1978) \\
\hline F. fusca & $95 \cdot 71 *$ & Germany & Schuster \& Neumann (1988) \\
\hline F. fusca glebaria (2) & $0 \cdot 20$ & Czech Republic & Groschaft (1961) \\
\hline F. glebaria $(2)$ & $0 \cdot 04$ & Rumania & Fromunda et al. (1965) \\
\hline \multirow[t]{2}{*}{ F. lugubris } & $0 \cdot 1$ & Bosnia-Herzegovina & Jonlija et al. (1973) \\
\hline & $95 \cdot 8 *$ & & \\
\hline \multirow[t]{2}{*}{ F. lugubris } & $0 \cdot 14$ & Bosnia-Herzegovina & Rozman et al. (1974) \\
\hline & $71 \cdot 9 *$ & & \\
\hline F. mesasiatica & $1 \cdot 3-2 \cdot 08$ & Russia & Urazbaev (1979) \\
\hline$F$. nigricans $(3)$ & $0 \cdot 11$ & Rumania & Fromunda et al. (1965) \\
\hline$F$. pratensis & 28 & Kazakhstan & Dementev (1968) \\
\hline$F$. pratensis & $33 \cdot 4$ & Bulgaria & Denev et al. (1970) \\
\hline$F$. pratensis & $83 \cdot 38 *$ & Bulgaria & Srivastava $(1975)$ \\
\hline$F$. pratensis & $0 \cdot 09-0 \cdot 45$ & Ukraine & Klesov \& Popova $(1958,1959)$ \\
\hline$F$. pratensis & $0 \cdot 38$ & Czech Republic & Groschaft (1961) \\
\hline$F$. pratensis & $0 \cdot 18$ & Spain & Del Río (1967) \\
\hline \multirow[t]{2}{*}{$F$. pratensis } & $0 \cdot 1$ & Bosnia-Herzegovina & Jonlija et al. (1973) \\
\hline & $95 \cdot 8 *$ & & \\
\hline \multirow[t]{2}{*}{$F$. pratensis } & $1 \cdot 04$ & Bosnia-Herzegovina & Rozman et al. (1974) \\
\hline & $70 \cdot 4 *$ & & \\
\hline F. picea & $0 \cdot 57$ & Central Caucasus & Popov \& Kalitina (1962) \\
\hline \multirow[t]{2}{*}{$F$. polyctena } & 0 & Bosnia-Herzegovina & Jonlija et al. (1973) \\
\hline & $15 \cdot 9 *$ & & \\
\hline \multirow[t]{2}{*}{$F$. polyctena } & 0 & Bosnia-Herzegovina & Rozman et al. (1974) \\
\hline & $16 \cdot 8 *$ & & \\
\hline F. rufibarbis & $0 \cdot 50$ & Spain & Del Río (1967) \\
\hline F. rufibarbis & $0 \cdot 47$ & Serbia & Vujic (1972) \\
\hline F. rufibarbis & $2-3$ & Lebanon and Syria & Tohmé \& Tohmé (1977) \\
\hline F. rufibarbis & $0 \cdot 92$ & Macedonia & Angelovski \& Iliev (1978) \\
\hline$F$. sanguinea & $0 \cdot 50$ & Spain & Del Río (1967) \\
\hline F. subpilosa & $13 \cdot 4$ & Tajikistan & Dil'man (1978) \\
\hline
\end{tabular}

$(1)=$ Cataglyphis $;(2)=$ Formica cunicularia $;(3)=$ Formica pratensis according to Seifert (1992). * Collected in tetania.

and autumn by Schuster (1993). This means that slimeballs could be shed mainly during the mentioned periods. Veselinov (1962) observed that Zebrina detrita shed slimeballs from May to July in Bulgaria; Hohorst \& Lämmler (1962) detected them in Germany from May to October.

The size of $D$. dendriticum daughter sporocysts from $H$. corderoi was smaller than that of the specimens of $H$. itala studied in this paper and in another studied by Manga-González (1987), possibly due to the smaller size of the $H$. corderoi specimens.

\section{Ants}

According to our results $F$. cunicularia, F. rufibarbis, $F$. pratensis and $F$. sanguinea act as second intermediate hosts of $D$. dendriticum in the Porma mountain region and $F$. rufibarbis also in the flat study area. The ant infection prevalence obtained by us (Table 4) and by other authors (Table 8) varied among the different species but mainly due to the type of sampling. So infection of $F$. pratensis collected directly from the anthills by us was very low $(4.05 \%)$ in comparison with that obtained in ants gathered in tetania $(100 \%)$; the same applied to F. rufibarbis $(6.59 \%$ and $95.39 \%$, respectively). This coincides with what was seen in $F$. lugubris, $F$. pratensis and $F$. polyctena by Jonlija, Milka \& Cankovic (1973) and Rozman et al. (1974).

The fact that not all the ants collected in tetania hosted metacercariae of $D$. dendriticum in the abdomen could be because not all the brains of the dissected ants were examined. So it cannot be ruled out that they only contained the brainworm (or worms) which alter their behaviour. Non-infection could also be due to some ants not in tetania being 
collected amongst others in that stage on the same plant. It also has to be considered that infection by the fungus Entomophthora produces behaviour in ants similar to that caused by $D$. dendriticum, which makes them climb plants and grip them in the same way (Loos-Frank \& Zimmermann, 1976).

The number of $D$. dendriticum metacercariae per ant found by us and by other authors (Table 5) varied among the different species and even within the same one. This variability could be due to: the time of year, as it is higher in summer (Paraschivescu, Hurghisiu \& Popescu, 1976); the different affinity of the ant species for slimeballs (Loos-Frank, 1978); the type of vegetation and the ant species (Paraschivescu, 1978); the size of the abdomen of the different formicidae, greater in those that have a large abdomen (Kalkan, 1976); and the different species of ant, the size of each ant - the number of metacercariae in the abdominal cavity of ants is proportional to the amount of space available to them - and, moreover, possibly ecological and behavioural causes (Schuster, 1991).

We only found one $D$. dendriticum brainworm in the ventral part of the suboesophageal ganglion of the ant specimens examined, as did Anokhin (1966) in F. pratensis. Hohorst \& Graefe (1961) and Hohorst (1962) confirmed the existence of a worm in the suboesophageal ganglion but sometimes in cases of superinfections, up to 2 or 3 metacercariae can be found in the brain of the same ant. Carney (1969) also comments that one, two or three $D$. dendriticum cercariae without tails cross the craw, arrive at the haemocele and then the suboesophageal ganglion where they encyst. Romig, Lucius \& Frank (1980) using histological examination of the ant $(F$. polyctena and $F$. rufa) brains observed that most ants infected with $D$. dendriticum have only one brainworm which settles in the suboesophageal ganglion in $90 \%$ of cases. There the larva was mainly situated in the ventral part in close contact with the origin of the mandibular nerves. These authors also found $D$. dendriticum larvae in the optic and antennal lobes and between the antennal lobe and the suboesophageal ganglion. Therefore they do not consider it clear whether the alteration in the behaviour of infected ants occurs because of a mechanical influence on the surrounding nerve tissue by the brainworm, since the larva located in the optic lobules or other parts of the brain induces the same changes in behaviour as the brainworm situated in the suboesophageal ganglion. This made them think it more likely that metabolic products influence the nervous system of the ant. The substances could be produced in the brainworm and the metacercariae from a certain stage of maturity. We could not find a cyst wall in the parasite larvae situated in the suboesophageal ganglion, as happened in most of the cerebral stages found by Romig et al. (1980).

The number of $F$. pratensis ant specimens in tetania found by us in the area around each anthill $(1-9, \bar{x}=5)$ was slightly lower than that observed by Badie (1979) $(\overline{\mathrm{x}}=7-8)$ and much lower than those found by Paraschivescu (1981b) in F. pratensis (2-57) and Spindler, Zahler \& Loos-Frank (1986) in $F$. polyctena (70). The most frequently occurring position of $F$. pratensis in tetania, fixed on different plant species around the anthill was head down, coinciding with what was indicated by Badie \& Rondelaud (1988) in their studies of $F$. nigricans ( $=F$. pratensis) and $F$. cunicularia in France. Spindler et al. (1986) found half of the ants ( $F$. polyctena) on grasses forming a ring around the nest; most of the others were found up to $3.65 \mathrm{~m}$ from the nest, and some up to $14 \mathrm{~m}$. By following the infected ants marked with coloured nail varnish, they observed that the choice of specific plant species as a support depended on relative abundance. Moreover the authors observed that most of the ants $(55 \%)$ attached themselves to plants with flowers and mainly preferred the blossoms $(74 \%)$. We also observed this, mainly in the numerous specimens of $F$. rufibarbis collected in the flat area. Paraschivescu (1981a) found ants on plants situated at a distance of one metre from the top of the nest, on different organs, such as the main nerve of the lower face of the foliar limb, on the corolla and on the edge of the limb. Paraschivescu \& Raicev (1980) observed that in $F$. pratensis in tetania there were non-rhythmical movements of legs, gaster and antennae followed by rest periods. They found by marking ants in tetania and the plant parts that some of the ants remain for a longer period of time and return to the same place on the plant, even after 4 days, but others are not constant.

The changes in behaviour of the infected ants are mainly regulated by fluctuations in the ambient temperature, due to which the availability of metacercariae to the grazing animals has a circadian rhythm. The tetania of the infected ants normally occurs when solar intensity and temperature decrease at the end of the afternoon and disappears in the morning when insolation and temperature increase. The alteration in ant behaviour favours ingestion of the parasite by the definitive host. We usually observed the greatest number of ants in tetania in the early hours of the morning and late in the afternoon (Fig. 9), as did most authors. However, on cloudy or warmer days we also detected ants in tetania at the end of the morning and beginning of the afternoon $\left(17-20^{\circ} \mathrm{C}\right)$. These results coincide with what was indicated by Spindler et al. (1986) who once observed that $10 \%$ of the 70 ants which were in tetania at 6.30 (at $4{ }^{\circ} \mathrm{C}$ ) continued in that condition between 14.00 and $15.00 \mathrm{~h}$, when the highest temperature was reached $\left(17.5{ }^{\circ} \mathrm{C}\right)$. In addition these authors observed that, even in the middle of the day when the temperature was $20.5{ }^{\circ} \mathrm{C}$, new ants arrived and attached themselves. They think that most of the ants attach themselves either at nightfall or (less 
likely) in the early morning. For Badie et al. (1973) the number of infected ants (F. cunicularia and $F$. nigricans) fixed to grass increased at low temperatures (9 to $10^{\circ} \mathrm{C}$ ) and decreased at higher temperatures (about 24 to $26^{\circ} \mathrm{C}$ ). The highest temperature at which we observed ants in tetania, $26.9{ }^{\circ} \mathrm{C}$ in the mountains and $28{ }^{\circ} \mathrm{C}$ in the flat area, was higher than that stated by Jonlija et al. (1972) $21^{\circ} \mathrm{C}$, Paraschivescu (1983) $18-20^{\circ} \mathrm{C}$, Schuster (1991) below $18{ }^{\circ} \mathrm{C}$ and Spindler et al. (1986) $20^{\circ} \mathrm{C}$, amongst others.

We observed active ants between March and November, infected ones from April to November in those collected from the nest and in tetania between May and October. The ants could be infected throughout their activity period, as sporocysts with well-developed cercariae were observed in January and from April to December. In Germany, Hohorst \& Lämmler (1962) observed most of the attached ants $(F$. rufibarbis and $F$. cunicularia) in spring and autumn, collecting the former in the middle of March and the latter at the end of October. In Kazakhstan Dementev \& Karabaev (1968) found the highest $D$. dendriticum infection values in spring and autumn and the minimum in summer in $F$. pratensis. In Bosnia-Herzegovina, Jonlija et al. (1972) observed the largest number of infected ants in September and October and Rozman et al. (1974) observed the greatest number in tetania in April. This decreased during the summer and increased again in September. In France, Badie (1975) observed that the maxima obtained in June and August (1973) and in April and September (1974) were preceded by heavy rains. Badie (1978) comments that it is not possible to consider the hypothesis that two welldefined ant infection periods exist because, although he observed infected ants (F. cunicularia and $F$. nigricans) in tetania between March and November, the infection rate varied with the year and month. The highest number of attached ants was detected in April 1974, June 1973, July 1975 and June 1976. In Russia, Urazbaev \& Sumakovich (1981) observed the highest number in tetania between May and July, but considered that the definitive hosts can be infected throughout the grazing season (MaySeptember). In the Republic of Georgia, Chitiashvili (1982) saw ants in tetania between April and June. In Germany, Paraschivescu (1983) mainly observed them in spring and Schuster (1991) collected them April to October.

Parasite transmission to the definitive hosts only occurs at the times when the ants are not hibernating. Nevertheless, the survival of the metacercariae in hibernating ants plays an important role in the epidemiology of dicrocoeliosis. Badie (1978) believes that some of the ants detected in March-April were infected at the end of autumn and during the winter of the previous year. Tarry (1969) states that the metacercariae can remain in the abdomen of the ant for a year or more without affecting its survival and thus the parasite spends the winter and makes the pasture infective again in spring. In our study, specimens of $F$. rufibarbis collected in the field in tetania survived in the laboratory, kept and fed in artificial nests, for up to 6.5 months, whilst Paraschivescu (1981c) states that the infected ants starve and die near the anthill and the same occurs when they are transferred to the laboratory and kept at room temperature. According to Dementev (1979) none of the ants collected in tetania survived for 25 days. Spindler et al. (1986) stated that the ants do not readily die from starvation and can be kept without food for many days provided that the conditions are moist enough. Wolff (1976) carried out autopsies (50 days after exposure) on a group of ovines, which remained on $D$. dendriticum-contaminated Swiss pastures, and others from groups kept there for only 19 days, at different times during the grazing season. Wolff suggested that infection occurs continually, although the highest rate was recorded in April - May, due to the ingestion of metacercariae which survived the winter, and the lowest in October.

The size of $D$. dendriticum encysted metacercariae from $F$. rufibarbis collected in tetania was similar to that given by other authors for metacercariae extracted from different ant species and the thickness of the cyst wall was, in general, lower (Table 6). Schuster (1991) calculated the volume of metacercarial cysts and noted that it depended mainly on the burden per ant and the size of the ant, but was not influenced by the species or time of collection. Rosicky \& Groschaft (1982) stated that the cyst size depended on the number of encysted metacercariae in the intermediate host. The cyst wall consists of 4 layers: an external fibrous one $(0.42 \mu \mathrm{m}$ thick $)$, a hyaline one $(26.66 \mu \mathrm{m})$, an internal fibrous one $(0.46 \mu \mathrm{m})$ and an internal lipoprotein membrane, which immediately surrounds the larvae (Tverdokhlebov, 1984).

As regards the size of the excysted metacercariae (length $412.80-624 \mu \mathrm{m}, \quad \overline{\mathrm{x}}=510.33 \mu \mathrm{m}$; width $115.20-201.60 \mu \mathrm{m}, \quad \bar{x}=161.66 \mu \mathrm{m})$, the lengths were similar to or slightly under those observed by Klesov \& Popova (1959), $426 \mu \mathrm{m}$, and Krull \& Mapes (1953), $540-635 \mu \mathrm{m}$, and below those of Fromunda, Popescu \& Paraschivescu (1973), $758 \mu \mathrm{m}$, Paraschivescu et al. (1976), $753 \mu \mathrm{m}$, and Paraschivescu (1981a), $758 \mu \mathrm{m}$. The mean width was above that given by Klesov \& Popova (1959), $80 \mu \mathrm{m}$, and slightly above those stated by Paraschivescu et al. (1976), Fromunda et al. (1973) and Paraschivescu (1981a), 150, 151 and $151 \mu \mathrm{m}$, respectively.

\section{Metacercaria isoenzymatic study}

On comparing the results obtained in this paper on the LDH, GPI, PGM and AcP activity in the 
metacercariae extracted from the abdomen of $F$. rufibarbis with those recorded by Campo et al. (1998) in $D$. dendriticum adults, it seems that all the activity bands forming the metacercariae patterns correspond to those of some of the patterns found in the adults. However, in general a more reduced number of activity bands and a lower band intensity were detected in the larval stages than in the adults. This coincides with what was observed by Wright, Rollinson \& Goll (1979) who, on comparing the GPI patterns for the adult worms of Schistosoma haematobium, Paramphistomum microbothrium and Echinostoma revolutum with those of their respective larval stages, showed that the same bands of activity were present, although in the second and third species there were some additional bands and in all 3 the greater enzyme concentration in the adult extracts gave more intense patterns.

The activity band repeated in all the $\mathrm{LDH}$ models in the metacercariae was that situated at $\mathrm{pH} \mathrm{7 \cdot 08}$. This coincides with what was observed in the adults (Campo et al. 1998), although it was generally more intense in the case of the latter. As regards GPI, the common bands in the three models observed in the metacercariae were at $\mathrm{pH} 6.80$ and 6.54 , the latter being more intense, for both the metacercariae and the adults. In PGM the band at $\mathrm{pH} 6.20$ was observed in both models obtained in the metacercariae and was also the most repeated and intense in the 5 models of the adults. The AcP bands were observed in the metacercariae in a very narrow $\mathrm{pH}$ range between 5.91 and 5.92 , except a very weak AcP-1 model situated at 5.86. However, a band at $\mathrm{pH} 5 \cdot 70$ was always detected in the adults, although it was very weak.

The PGM-2 model is exactly the same in the metacercariae as in the adults and the PGM-1 of the former is differentiated from the PGM-4 of the latter only in the fact that the activity band at $\mathrm{pH} 6 \cdot 20$ is strong in the adults and very weak in the metacercariae. The GPI-2 model is common to both parasite development stages, except as regards the intensity of the 6.43 band, which is very weak in the metacercariae and strong in the adults.

In the isoenzymatic systems studied different patterns were generally observed in metacercariae extracted from the same ant, from ants from different places and sometimes from those collected in the same place. On the basis of the results obtained, the best enzymatic systems for the characterization of the $D$. dendriticum metacercariae from $F$. rufibarbis specimens were LDH, GPI and PGM.

\section{Approach to dicrocoeliosis epidemiology}

According to our field and experimental research the following epidemiological model can be deduced. $D$. dendriticum egg elimination by livestock occurs throughout the year, although the highest elim- ination takes place at the end of autumn and in winter-when the temperatures are lower. Considering that low temperatures do not affect egg survival, pasture contamination is very high at the end of winter and in spring. This facilitates egg ingestion by the molluscs which start to be active and are very abundant in spring. The molluscs infected at the beginning of this period could shed slimeballs with cercariae at the end of summer and during autumn, whilst those infected later can shed slimeballs the following year beginning in spring, if they survive the harsh winter. Approximately 45 days later the cercariae ingested by ants will have become infected metacercariae for the definitive hosts. This will allow the parasite cycle to be completed when the ants are ingested by ruminants on grazing, during the active period of the ants between March and November. Nevertheless, some infected ants survive hibernation in their nests during the winter and they are responsible for definitive host infection at the beginning of the spring. In the following months and until November, the risk of ruminant infection increases, due to the fact that, together with the above-mentioned ants, others infected by ingestion of the slimeballs shed by the infected molluscs that survive the winter, or by the ones that ingested eggs of the parasite at the end of winter or beginning of spring, will also be available in the pasture.

Therefore, the ingestion of the infective metacercariae (contained in the ants) by the definitive hosts and the number of $D$. dendriticum adult worms in the liver of the animals increase with the activity period of the ants. As a consequence of this, egg elimination reaches the highest values in January-February, that is, about two months after the last ingestion of the infected ants, before hibernation starts.

\section{ACKNOWLEDGEMENTS}

We wish to express our deep gratitude to: M. L. Carcedo, C. Espiniella and M. P. Del Pozo (CSIC, León) for their technical assistance; C. Otero, biologist, for her enthusiastic collaboration, mainly on ants; Dr Wiktor (Wroclaw, Poland) and Drs Gómez and Altonaga (Bilbao, Spain) for their help in the identification of some mollusc species; Drs Espadaler (Barcelona, Spain) and Collingwood (Leeds, U.K.) for ant identification; Dr Espadaler for helping us to see ants in tetania and the brainworm in the suboesophageal ganglion. This study was supported by the "Junta de Castilla y León" (Project No. 0701/89), by the British Council-Spanish Ministry of Education and Science (Joint Research Programme 19911993) and by the Spanish CICYT (Projects No. AG920588, 1FD97-0776 and 1FD97-1313-CO2-02).

\section{REFERENCES}

ALUNDA, J. M. \& ROJO, F. A. (1983). Effect of infection rate and host age on the intramolluscan development of Dicrocoelium dendriticum. Helminthologia 20, 251-258. 
ANGElovski, T. \& ILIEv, A. (1978). The species of ants and their role in biology of Dicrocoelium dendriticum in SR Macedonia. Proceedings of the Second European Multicolloquium of Parasitology, 1-6 September, 1975, Trogir, Yugoslavia. Association of Yugoslav Parasitologists, Belgrade, 163-166.

ANokhin, I. A. (1966). [Diurnal cycle of the activity and behaviour of ants (Formica pratensis Retz.) invaded by metacercaria of Dicrocoelium lanceatum during the grazing period). Zoologicheskie Zhurnal 45, 687-692.

BADIE, A. (1975). Cycle annuel d'activité des fourmis parasitées par les métacercaires de Dicrocoelium lanceolatum (Rudolphi, 1819). Annales de Recherches Vétérinaires 6, 259-269.

BADIE, A. (1978). La dicroceliose ovine: incidence des facteurs climatiques et contribution à la mise au point d'une méthode de prévision. Annales de Parasitologie Humaine et Comparée 53, 373-385.

BADIE, A. (1979). La petite douve Dicrocoelium lanceolatum ou Dicrocoelium dendriticum ${ }^{-}$ses hôtes intermédiaires. Pâtre 268, 51-54. .

BADIE, A. \& RONDELAUD, D. (1987). Les mollusques hôtes intermédiares de Dicrocoelium lanceolatum Rudolphi. A propos de quinze années d'observations. Bulletin de la Société Française de Parasitologie 5, 105-108.

BADIE, A. \& RONDELAUD, D. (1988). Les fourmis parasitées par Dicrocoelium lanceolatum Rudolphi in

Limousin. Les relations avec le support végétal. Revue de Médecine Vétérinaire 139, 629-633.

BADIE, A., VINCENT, M., MOREL-VAREILLE, C. \& Rondelaud, D. (1973). Cycle de Dicrocoelium dendriticum (Rudolphi, 1819) en Limousin. Ethologie des fourmis parasitées par les métacercaires. Comptes Rendus des Séances de la Société de Biologie 167, 725-727.

Bocharova, M. M. (1983). (Foci of dicrocoeliasis in the mountain forest-steppe of the northern slopes of the central Caucasus). In Fauna i Ékologiya Zhivotnykh Severnykh Sklonov Tsentral'nogo Kavkaza. (Mezhvuzovskii Sbornik). Ordzhonikidze; USSR; Severo-Osetinskii Gosudarstvennyi Institut, 10-13 BONavita, D. (1961). Conditions de la production de l'épiphragme chez quelques mollusques Hélicides. Comptes rendus hebdomadaires des séances de l'Académie des sciences (Paris) 253, 3101-3102. BORAY, J. C. (1985). Flukes of domestic animals. In Parasites, Pests and Predators. (World Animal Science, B2) (ed. Gaafar, S. M., Howard, W. E. \& Marsh, R. E.), pp. 179-218. Amsterdam, Elsevier Science Publishers B. V.

CAMPo, R., MANGA-GONZÁLEZ, M. Y. \& GONZÁLEZ-LANZA, C. (2000). Relationship between egg output and parasitic burden in lambs experimentally infected with different doses of Dicrocoelium dendriticum (Digenea).

Veterinary Parasitology 87, 139-149.

CAMPO, R., MANGA-GONZÁLEZ, M. Y., GONZÁLEZ-LANZA, C. \& DEL-POZo, P. (1992). Detección isoenzimática de las primeras fases larvarias de Dicrocoelium dendriticum (Trematoda) en moluscos hospedadores intermediarios infestados experimentalmente. Cuadernos de Investigación Biológica 17, 44.

CAMPO, R., MANGA-GONZÁLEZ, M. Y., GONZÁLEZ-LANZA, C., ROLlinson, D. \& SANDOval, H. (1998). Characterization of adult Dicrocoelium dendriticum by isoelectric focusing. Fournal of Helminthology 72, 109-116. CARNEY, W. P. (1969). Behavioral and morphological changes in carpenter ants harboring dicrocoeliid metacercariae. The American Midland Naturalist 82, 605-611.

Castillejo, J. (1998). Guía de las Babosas Ibéricas. Santiago de Compostela (España), Real Academia Galega de Ciencias.

CAVANi, C., Losi, G., MANFREdini, M., PAVoncelli, R. M., PIETROBElli, M. \& RESTANi, R. (1982). Ricerche sull'influenza della dicroceliasi sulle caratteristiche quantitative e qualitative della produzione di latte in pecore. Obiettivi e Documenti Veterinari 3, 59-63.

Chitiashvili, B. G. (1982). [Effect of temperature and relative humidity on the activity of infected ants]. Nauchnye Trudy, Gruzinskii ZootekhnicheskoVeterinarnyi Institut 127, 32-34.

COLlingwood, C. A. (1978). A provisional list of Iberian Formicidae with a key to the worker caste (Hym. Aculeata). EOS 52, 65-95.

CORdero, M., CASTAÑón, L. \& REguera, A. (1994). Índicecatálogo de Zooparásitos lbéricos. Universidad León (España), Secretariado de Publicaciones.

DEL RIO, J. (1967). Epizootiología de la dicroceliosis en la provincia de León. Anales de la Facultad de Veterinaria de León 13, 211-253.

DEMENTEV, I. S. (1968). (Epizootiology of dicrocoeliasis of sheep in south-eastern Kazakhstan). Materiali Seminara-Soveshchaniya po Borbe s Gel'mintozami sel'.-khoz. Zhivotnikh v Chimkente, Alma-Ata, 56-58.

DEMENTEv, I. S. (1979). [The role of abiotic ants from the genus Formica in the epizootiology of dicrocoeliasis]. Materialy respublikanskogo seminara po bor'be s parazitarnymi boleznyami sel'skokhozyaistvennykh zhivotnykh, posvyashchennogo 100-letiyu so dnya rozhdeniya Akademika K. I. Skryabina. Alma-Ata, USSR, 42-47.

DEMENTEV, I. S. \& KARABAev, D. K. (1968). (Infection of terrestrial molluscs and ants by Dicrocoelium dendriticum larvae in southeastern Kazakhstan). Vestik sel'-skokhozyaistvennoi Nauki, Alma-Ata 12, 51-55.

Denev, I., SAvova, S., Stolmenov, K., TAHirov, B., Donev, A., KASSABOV, R. \& PETKOV, P. (1970). [An investigation into the dicrocoeliosis in north-eastern

Bulgaria. II. On the intermediary and additional hosts of Dicrocoelium lanceatum Stiles et Hassall, 1896]. Veterinamomeditsinski Nauki, Sofia 7, 23-31.

DHAR, D. N. \& SINGH, H. s. (1963). Pathology of liver in dicrocoeliasis. Indian Fournal of Veterinary Science and Animal Husbandry 33, 200-210.

DIL'MAN, P. N. (1978). [Formica subpilosa Ruzs, a new second intermediate host of Dicrocoelium lanceatum Stiles et Hassall, 1895 (D. lanceolatum)]. Trudy Nauchno-Issledovatel'skogo Veterinarnogo Instituta Tadzhikskoi SSR 8, 88-89.

ECKert, J. \& Hertzberg, H. (1994). Parasite control in transhumant situations. Veterinary Parasitology 54, 103-125.

ENGEL, H. (1957). Oekologisch-faunitische Studien im Rhône-delta, unter besonderer Berücksichtigung der Mollusken. Bonner Zoologische Beiträge 8, 5-55. FERRERAS, M. C., GARCÍA-IGLESIAS, M. J., MANGA-GONZÁLEZ, 
M. Y., PÉREZ, C., CAMPO, R., GONZÁLEZ-LANZA, C., ESCUDERO, A. \& GARCÍA-MARÍN, J. F. (1997). Lesiones hepáticas en corderos infectados experimentalmente con Dicrocoelium dendriticum. Acta Parasitológica Portuguesa 4, 86.

FERrERAS, M. C., MANGA-GONZÁLEZ, M. Y., PÉREZ, C., GARCíA-IGLESIAS, M. J., CAMPO, R., GONZÁLEZ-LANZA, C., ESCUDERO, A. \& GARCÍA-MARÍN, J. F. (2000). Local immune response to experimental ovine dicrocoeliosis. Acta Parasitologica 45, 198.

Fromunda, v., PARAschivescu, D. \& POPEsCu, s. (1965). Cercetari privind gazdele complementare pentru Dicrocoelium lanceatum in Republica Socialista Romania. Lucrarile ICVB Pasteur 4, 269-280.

Fromunda, v., POpescu, s. \& PARAschivescu, D. (1973). Contributions à la connaissance des formes larvaires et pré-imago du trematode Dicrocoelium lanceatum (Stiles et Hassall, 1896). Archiva Veterinaria 10, 85-91.

GÓMEZ, B. J., MANGA-GONZÁLEZ, M. Y., ANGULO, E. \& GONZÁLEZ-LANZA, C. (1996). Alteraciones histológicas producidas por Dicrocoelium dendriticum (Trematoda) en dos especies de Cernuella (Mollusca) sacrificadas a los tres meses post-infestación. Iberus 14, 189-195.

GONZÁLEZ-LANZA, C., MANGA-GONZÁlEZ, M. Y., CAMPO, R. \& DEL-POZO, P. (1997). Larval development of Dicrocoelium dendriticum in Cernuella (Xeromagna) cespitum arigonis under controlled laboratory conditions. Fournal of Helminthology 71, 311-317. GONZÁLEZ-LANZA, C., MANGA-GONZÁlEZ, M. Y., CAMPO, R., DEL-POZO, P., SANDOVAL, H., OLEAGA, A. \& RAMAJO, V. (2000). IgG antibody response to $\mathrm{ES}$ or somatic antigens of Dicrocoelium dendriticum (Trematoda) in experimentally infected sheep evaluated by ELISA. Parasitology Research 86, 472-479.

GONZÁLEZ-LANZA, C., MANGA-GONZÁLEZ, M. Y. \& DELPOzo, P. (1993). Coprological study of the Dicrocoelium dendriticum (Digenea) egg elimination by cattle in highland areas in León Province, Northwest Spain. Parasitology Research 79, 488-491.

GRoschaft, J. (1961). Mravenci doplnkoví mezihostitelé motolice kopinaté (Dicrocoelium dendriticum Rudolphi 1819)]. Ceskoslovenská Parasitologie 8, 151-165.

HINAIDY, H. K. (1983). Dicrocoelium suppereri nomen novum (syn. D. orientalis Sudarikov et Ryjikov 1951), ein neuer Trematode für die Parasitenfauna Österreichs. Zentralblatt für Veterinärmedizin B 30, 576-589.

Hohorst, w. (1962). Die Rolle der Ameisen im Entwicklungsgang des Lanzettegels (Dicrocoelium dendriticum). Zeitschrift für Parasitenkunde 22, 105. HOHORST, W. \& GRAEFE, G. (1961). Ameisen-

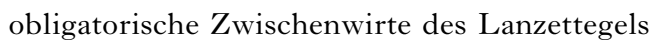
(Dicrocoelium dendriticum). Naturwissenschaften, Berlin 48, 229-230.

HOHORST, W. \& LÄMMLER, G. (1962). Experimentelle Dicrocoeliose-Studien. Zeitschrift für Tropenmedizin und Parasitologie 13, 377-397.

JONLija, R., CANKOviC, M. \& ROZMAN, M. (1972).

Examination of ants the second intermediary hosts of Dicrocoelium lanceatum in Bosnia and Hercegovina, I. Veterinaria 21, 317-322.

JONlija, R., Milka, R. \& CANKOVIC, M. (1973). Ispitivanje infestiranosti puzeva i mrava razvojnim oblicima
Dicrocoelium lanceatum u Bosni i Hercegovini II. Veterinaria, Sarajevo 22, 449-470.

Kalkan, A. (1970). Dicrocoelium dendriticum (Rudolphi, 1819) Looss, 1899 in Turkey. 1. Field studies of intermediate and final hosts in the South Marmara region, 1968. British Veterinary Fournal 127, 67-75.

Kalkan, A. (1976). [Dicrocoelium dendriticum in Turkey. 2. Observations on second intermediate hosts (ants) in the South Marmara Region]. Etlik Veteriner Bakteriyoloji Enstitüsü Dergisi 4, 11-37.

KARANFILOvSKI, G. (1983). Economic losses caused by fascioliasis and dicrocoeliasis to livestock production in Pljevlja and surrounding area. Veterinaria Yugoslavia 32, 253-260.

KERNEY, M. P., CAMERON, R. A. D. \& JUngbluth, J. H. (1983). Die Landschnecken Nord-und Mitteleuropas. Hamburg und Berlin, Verlag Paul Parey.

KLESOV, M. D. \& POPOVA, Z. G. (1958). [The biology of Dicrocoelium dendriticum (Stiles \& Hassall, 1896) - the agent of dicrocoeliasis in ruminants]. Zoologicheski Zhurnal 37, 504-510.

KLESOV, M. D. \& POPOVA, Z. G. (1959). [Study of the biology of Dicrocoelium and the epizootiology of dicrocoeliasis in ruminants]. Nauchnie Trudi Ukrainski Nauchno-Issledovatelski Institut Eksperimentalnoi Veterinarii 25, 5-18.

KRULL, W. H. \& MAPES, C. R. (1952). Studies on the biology of Dicrocoelium dendriticum (Rudolphi, 1819) Looss, 1899 (Trematoda: Dicrocoeliidae), including its relation to the intermediate host, Cionella lubrica (Müller). VII. The second intermediate host of Dicrocoelium dendriticum. Cornell Veterinarian 42 , 603-604.

KRULL, W. H. \& MAPES, C. R. (1953). Studies on the biology of Dicrocoelium dendriticum (Rudolphi, 1819) Looss, 1899 (Trematoda: Dicrocoeliidae), including its relation to the intermediate host, Cionella lubrica (Müller). IX. Notes on the cyst, metacercaria, and infection in the ant, Formica fusca. Cornell Veterinarian 43, 389-410.

KUZ'Movich, L. G. \& Kostinik, I. M. (1975). (The occurrence of Dicrocoelium lanceatum Stiles et Hassall, 1896 in Helicopsis instabilis). In Problemy Parazitologii. Materialy VIII nauchnoi konferentsii parazitologov UkSSR 1, 289-291.

LA RUE, G. (1957). Parasitological reviews. The Classification of Digenetic Trematoda: A Review and a New System. Experimental Parasitology 6, 306-349.

Loos-Frank, B. (1978). Zum Verhalten von Ameisen der Gattung Formica (Hymenoptera: Formicidae) gegenüber Schleimballen des Kleinen Leberegels Dicrocoelium dendriticum (Digenea: Dicrocoeliidae) und über Infektionsbedingte Veränderungen ihrer Hämolymphe. Entomologica Germanica 4, 12-23.

LoOS-FrAnk, B. \& ZimMERMANn, G. (1976). Über eine dem Dicrocoelien-Befall analoge Verhaltensände-rung bei Ameisen der Gattung Formica durch einen Pilz der Gattung Entomophthora. Zeitschrift für Parasitenkunde 49, 281-289.

Lucius, R. (1981). Untersuchungen zur Biologie, Pathologie und Ökologie von Dicrocoelium hospes Looss, 1907 (Trematodes, Dicrocoeliidae). Dissertation zur Erlangung des Grades eines Doktors 
der Naturwissenschaften vorgelegt der Fakultät II (Biologie) der Universität Hohenheim.

LUKIN, A. K. (1980). (The prevalence and economic loss due to dicrocoeliasis in ruminants). Trudy Saratovskoi Nauchno-Issledovatel'skoi veterinarnoi Stantsii 14, 76-79.

MaleK, E. A. (1980). Snail-Transmitted Parasitic Diseases. Vol I \& II, Florida, CRC Press, Inc.

MANGa-gONZÁleZ, M. Y. (1983). Los Helicidae

(Gastropoda, Pulmonata) de la Provincia de León. Institución "Fray Bernardino de Sahagún”, Excma. Diputación Provincial de León, Consejo Superior de Investigaciones Científicas (CECEL), León (España) MANGA-GONZÁLEZ, M. Y. (1987). Some aspects of the biology and helminthofaune of Helicella (Helicella) itala (Linnaeus, 1758) (Mollusca). Natural infection by Dicrocoeliidae (Trematoda). Revista Ibérica de Parasitología, Volumen extraordinario Enero 1987, 131-148.

MANGA-GONZÁLEZ, M. Y. (1992). Some land molluscs species involved in the life cycle of Dicrocoelium dendriticum (Trematoda) in the wild in the province of León (NW Spain). In Abstracts of the 11th

International Malacologial Congress, Siena (ed. Giusti, F. \& Manganelli, G.), pp. 248-249. Italy, Unitas Malacological. University of Siena.

MANGA-GONZÁLEZ, M. Y. (1999). Trematodos. In Parasitología Veterinaria (ed. Cordero-del-Campillo, M. \& Rojo-Vázquez, F. A.), pp. 79-104. Madrid, McGraw-Hill. Interamericana.

MANGA-GONZÁLEZ, M. Y., GONZÁLEZ-LANZA, M. C. \& DELPozo, P. (1991). Dynamics of the elimination of Dicrocoelium dendriticum (Trematoda, Digenea) eggs in the faeces of lambs and ewes in the Porma Basin (León, NW Spain). Annales de Parasitologie Humaine et Comparée 66, 57-61.

MANGA-GONZÁLEZ, M. Y. \& QUIROZ-ROMERO, H. (1999). Dicroceliosis. In Parasitología Veterinaria (ed. Cordero-del-Campillo, M. \& Rojo-Vázquez, F. A.), pp. 272-282. Madrid, McGraw-Hill. Interamericana. MAPES, C. R. (1951). Studies on the biology of Dicrocoelium dendriticum (Rudolphi, 1819) Looss, 1899 (Trematoda: Dicrocoeliidae), including its relation to the intermediate host, Cionella lubrica (Müller). I. A study of Dicrocoelium dendriticum and Dicrocoelium infection. Cornell Veterinarian 41, 382-432.

MOHAMED, A. R. E. \& MUMmery, v. (1990). Human dicrocoeliosis. Report on 208 cases from Saudi Arabia. Tropical and Geographical Medicine 42, 1-7.

oDENING, K. (1969). Der Lanzettegel oder Kleine Leberegel (Dicrocoelium dendriticum). Merkblätter über Angewandte Parasitenkunde und Schädlingsbekämpfung (Supplement Angewandte Parasitologie, 10) No. 16, 265-281.

ORTIZ DE ZÁRATE, A. (1950). Observaciones anatómicas y posición sistemática de varios helícidos españoles. III. (Especies de los subgéneros Candidula, Helicella sensu stricto, Xerotricha, Xeromagna y Pseudoxerotricha nov. subg.). Boletín de la Real Sociedad Española de Historia Natural 48, 21-85.

ovcharenko, D. A. (1964). (The biology of Dicrocoelium dendriticum in deer preserves in the Far East). Vestnik Leningradskogo Universitata. Seriya Biologii 19, 35-39. PARASCHIVESCU, D. (1976). (Dynamics of tetany in ants in some pastures infested with Dicrocoelium in Romania). Studii si Comunicari, Muzeul de Stiintele Naturii

Bacau 9, 65-77.

Paraschivescu, D. (1978). Dynamics of formicids (Hym., Formicidae) in tetany in some meadows with dicrocelioza in Romania. Travaux du Muséum d'Histoire Naturell 'Grigore Antipa' 19, 321-323.

PARASCHIVESCU, D. (1981a). Etho-ökologische Untersuchungen an einigen Formiciden-Arten als Zwischenwirte von Dicrocoelium dendriticum.

Waldhygiene 14, 65-72.

PARASCHIVESCU, D. (1981b). Untersuchungen zur künstlichen Infektion von Schaflämmern mit dem Kleinen Leberegel Dicrocoelium dendriticum Rudolphi

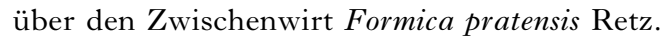
Waldhygiene 14, 73-78.

PARASCHIVESCU, D. (1981c). Experimentelle Untersuchungen zur Unterbrechung der Infektionskette beim Kleinen Leberegel Dicrocoelium dendriticum Rudolphi (Trematoda) durch Schutz der Nesthügel des Zwischenwirtes Formica pratensis Retz. (Formicidae). Waldhygiene 14, 79-84.

PARASCHIVESCU, D. (1983). Untersuchungen zur Temperaturabhangigkeit der Tetaniephase von Formica pratensis bei einer Infektion mit Stadien des Kleinen Leberegels Dicrocoelium dendriticum. Waldhygiene 15, 21-24.

PARAschivescu, D., HURGhisiu, I. \& POPESCU, s. (1976). Bioecologic and biochemical research upon Formicidae complementary hosts of the Dicrocoelium lanceatum fluke (Stiles and Hassall, 1896). Archiva Veterinaria 11/12, 159-178.

PARASCHIVESCU, D. \& RAICEV, C. (1980). Experimental ecological investigations on the tetany of the species Formica pratensis complementary host of the trematode Dicrocoelium dendriticum. Travaux $d u$ Muséum d'Histoire Naturelle "Grigore Antipa" 22, 299-302.

PIANA, P. (1882). Le cercarie nei molluschi studiata in rapporto colla presenza del Distoma epatico e del Distoma lanceolato nel fegato del ruminanti domestici. Clinica Veterinaria Milano 5, 306-314.

POPOV, K. K. \& KALITINA, A. I. (1962). (The development of Dicrocoelium dendriticum on high altitude grazing grounds of central Caucasus). Zoologicheski Zhurnal 41, 1793-1797.

RIDDLE, W. A. (1983). Physiological ecology of land snails and slugs. In The Mollusca. Ecology (ed W. D. Russell-Hunter) 6, 431-461. Orlando (Florida), Academic Press, Inc.

RIEDEL, A. (1972). Zur Kenntnis der Zonitidae (Gastropoda) Spaniens. Annales Zoologici, Warszawa 29, 115-145.

ROMING, T., LUCIUS, R. \& FRANK, W. (1980). Cerebral larvae in the second intermediate host of Dicrocoelium dendriticum (Rudolphi, 1819) and Dicrocoelium hospes Looss, 1907 (Trematodes, Dicrocoeliidae). Zeitschrift für Parasitenkunde 63, 277-286.

ROSICKY, B. \& GROSCHAFT, J. (1982). Dicrocoeliosis. In CRC Handbook Series in Zoonoses. Section C : Parasitic Zoonoses. Volume III (ed. Hillyer, G. V. \& Hopla, C. E.), pp. 33-52. Boca Raton, Florida, USA, CRC Press, Inc. 
ROZMAN, s., GRADJANIN, M. \& CANKOVIC, M. (1974). The transitory hosts of Dicrocoelium dendriticum in the mountain area of Bosnia and Herzegovina. Proceedings of the Third International Congress of Parasitology, Munich vol. 1, 513-514. Vienna, FACTA Publication. RozMAn, s., JONLiJA, R. \& MUSTAPiC, A. (1971).

Ispitivanje suhozemnih puzeva na razvajne oblike Dicrocoelium lanceolatum. Acta Parasitologica Yugoslavica 2, 99-103.

SÁNCHEZ-CAMPOS, S., TUÑóN, M. J., GONZÁLEZ, P., CAMPO, R., FERrERAS, M. C., MANGA-GONZÁLEZ, M. Y. \& GONZÁLEZ-GALLEGO, J. (1996). Effects of experimental dicrocoeliosis on oxidative drug metabolism in hamster liver. Comparative Biochemistry and Physiology 115C, 55-60.

schmidt, F. (1967). Zur Kentnis der Trematodenlarven aus Landmollusken. 11. Über eine Cercarie (Trematoda: Digenea: Dicrocoeliidae) aus Clausilia bidentata (Ström, 1765) und die zugehörige Metacercarie aus Isopoden. Zeitschrift für Parasitenkunde 29, 85-102.

sCHuster, R. (1987). Ein geschichtlicher Überblick zur Namensgebung des Lanzettegels Dicrocoelium dendriticum. Angewandte Parasitologie 28, 205-206. SCHUSTER, R. (1991). Factors influencing the metacercarial intensity in ants and the size of Dicrocoelium dendriticum metacercarial cyst. Fournal of Helminthologie 65, 275-279.

schuster, R. (1992). Zur Beeinflussung von Helicella obvia durch Dicrocoelium - Parthenitae. Angewandte Parasitologie 33, 61-64.

SCHUSTER, R. (1993). Infection patterns in the first intermediate host of Dicrocoelium dendriticum.

Veterinary Parasitology 47, 235-243.

SCHUSTER, R. \& NEUMANN, B. (1988). Zum jahreszeitlichen Auftreten von Dicrocoelium dendriticum in Zwischenwirten. Angewandte Parasitologie 29, 31-36.

SEIFERT, B. (1992). Formica nigricans, $1909-$ An ecomorph of Formica pratensis Retzius, 1783 (Hymenoptera, Formicidae). Entomologica Fennica 2, 217-226.

SPINDLER, E. M., ZAHLER, M. \& LOOS-FRANK, B. (1986). Behavioural aspects of ants as second intermediate hosts of Dicrocoelium dendriticum. Zeitschrift für Parasitenkunde 72, 689-692.

SRIVAstava, G. C. (1975). The intensity of infection in naturally infected Formica pratensis with the metacercariae of Dicrocoelium dendriticum in relation to their size. Fournal of Helminthology 49, 57-64.

STAIKOU, A., LAZARIDOU-Dimitriadou, M. \& KATTOUlas, M. E. (1989). Behavioural patterns of the edible snail Helix lucorum L. in the different seasons of the year in the field. Haliotis 19, 129-136.

TANG, C., TANG, Z., TANG, L., CUI, Q., LU, H. \& QIAN, Y. (1983). (Studies on the biology and epizootics of Dicrocoelium chinensis in the eastern inner Mongol Autonomous region). Acta Zoologica Sinica 29, 340-349.

TARRY, D. W. (1969). Dicrocoelium dendriticum: the life cycle in Britain. Fournal of Helminthology 43, 403-416.

TEGelströM, H., Nilsson, G. \& WYONi, P. I. (1983). Lack of species differences in isoelectric focused proteins in the Formica rufa group (Hymenoptera, Formicidae). Hereditas 98, 161-165.

TOHмÉ, H. \& TOHмÉ, G. (1977). Les hôtes intermédiares du cycle évolutif de la petite Douve du foie du mouton au Liban et en Syrie. Annales de Parasitologie Humaine et Comparée 52, 1-5.

TVERDOKHLEBOV, P. T. (1970). (Significance of different types of pastures in the infection of animals by Dicrocoelium). Byulleten' Vsesoyuznogo Instituta Gel' mintologii im. K. I. Skryabina 4, 147-149.

TVERDOKHLEBOV, P. T. (1984). [Morphology of the cyst wall and excystment mechanisms of Dicrocoelium lanceatum metacercariae]. In Gel'minty sel's kokhozyaistvennykh i okhotnich'e-promyslovykh zhivotnykh (ed. Sonin, M. D.), pp. 189-198. Moscow, USSR, Nauka.

URAZBAev, G. A. (1979). [The first and second intermediate hosts of Dicrocoelium lanceolatum in the interior of 'Tyan' Shan and the seasonal variations in the prevalence of infection]. Byulleten' Vsesosyuznogo Instituta Gel'mintologii im. K. I. Skryabina 24, 60-65.

URAZBAEv, G. A. \& SUMakovich, E. E. (1981). (The intermediate and additional hosts of Dicrocoelium lanceatum in the inner Tien-Shan region and the seasonal dynamics of their infectivity). Byulleten' Vsesosyuznogo Instituta Gel'mintologii im. K.l. Skryabina 24, 60-65.

vaught, к. C. (1989). A Classification of the Living Mollusca, Florida, American Malacologists, Inc.

VERSHININ, I. I. (1957). (Epizootiology of Dicrocoelium infections of sheep and its biology in the Kaluga region). Trudi Moskovskoi Veterinarnoi Akademii 19, 3-15.

VESELINOv, G. D. (1962). (Study of the development of Dicrocoelium dendriticum in Bulgaria). Izvestiya na Tsentralnata Khelmintologichna Laboratoriya Sofia 7, 127-135.

vON LINSTOW, D. (1887). Helminthologische Untersuchungen, Cercaria vitrina n.sp. Zoologische Fahrbücher. Abteilung für Systematik Oekologie und Geographie der Tiere (fena) 3, 105-106.

vujic, B. (1972). [Biology of Dicrocoelium lanceolatum (Rudolphi 1803) in some mountainous and flat areas in Serbia (II)]. Veterinarski Glasnik 26, 827-833.

WIKTOR, A. (2000). Agriolimacidae (Gastropoda: Pulmonata) - A Systematic Monograph. Annales Zoologici 49, 347-590.

WOlda, H., zWEeP, A. \& SCHUitema, K. A. (1971). The role of food in the dynamics of populations on the land snail Cepaea nemoralis. Oecologia 7, 361-381.

wolfF, K. (1976). Zur Epizootiologie der Dicrocoeliose des Schafes. Berliner und Münchener Tierärztliche Wochenschrift 89, 272-276.

WOlfF, K., Hauser, B. \& WILD, P. (1984). Dicrocoeliose des Schafes: Untersuchungen zur Pathogenese und zur Regeneration der Leber nach Therapie. Berliner und Münchener Tierärztliche Wochenschrift 97, 378-387.

WRIGHT, C. A., ROLLINSON, D. \& GOLL, P. H. (1979). Parasites in Bulinus senegalensis (Mollusca: Planorbidae) and their detection. Parasitology 79, 95-105. 